\title{
Properties of Aqueous Solutions of Perchloric Acid
}

\author{
By Langhorne H. Brickwedde
}

\begin{abstract}
Several properties of the sysiem $\mathrm{HClO}_{4}-\mathrm{H}_{2} \mathrm{O}$ for concentrations of $\mathrm{HClO}_{4}$ varying from 0 to 70 percent by weight have been measured from $-60^{\circ}$ to $+75^{\circ} \mathrm{C}$. These properties include density, viscosity, electrical resistivity, and freezing temperatures of the solutions. An empirical relation between electrical resistivity, kinematic viscosity, and temperature has been found to be of the same form as the relation which Vinal and Craig found for sulfuricacid solutions. The properties of perchloric-acid solutions of interest for battery work have been discussed. Some measurements of electrical resistivity of solutions containing the lead salt formed as a perchloric-acid battery discharges have been measured.
\end{abstract}

\section{Some Properties of Aqueous Solutions of Perchloric Acid}

\section{Introduction}

A study of several properties of the system $\mathrm{HClO}_{4}-\mathrm{H}_{2} \mathrm{O}$ for concentrations of $\mathrm{HClO}_{4}$ varying from 0 to 70 percent by weight has been made. The density, viscosity, and electrical resistivity of the system have been measured from $-60^{\circ}$ to $+75^{\circ} \mathrm{C}$. The freezing temperatures of some of the solutions have also been determined. The work was done as part of the project on perchloric-acid and similar batteries for the Bureau of Ships, Navy Department. Four reports ${ }^{1}$ were issued as the work progressed. These have since been declassified and made available for publication.

\section{Density \\ (a) Apparatus}

Two picnometers of 7.8 - and $15.5-\mathrm{ml}$ capacity were used in making the density measurements. Each picnometer consisted of a spherical bulb and a small-bore calibrated stem. The volumes in the stems were respectively 0.00995 and $0.00487 \mathrm{ml}$ per division. Volumes read with a hand lens were

1 (1) Resistivity of perchloric-acid solutions from $+50^{\circ}$ tc $-60^{\circ} \mathrm{C}$. Langhorne H. Brickwedde (May 1943). (2) Resistivity of perchloroic-acid solutions containing lead perchlorate, from $+75^{\circ}$ to $-40^{\circ} \mathrm{C}$. Langhorne $\mathrm{H}$. Brickwedde and Belen G. Pardo (August 1943). (3) Densities of perchloric-acid słlutions from $+50^{\circ}$ to $-50^{\circ} \mathrm{C}$. Langhorne $\mathrm{H}$. Brickwedde and Belen G. Pardo (January 1944). (4) Visec sity of perchloric-acid solutions from $+50^{\circ}$ to $-60^{\circ}$ C. Langhorne H. Brickwedde and Belen G. Pardo (August 1944). estimated at 0.05 division and easily repeated to 0.1 division. Two observers read volumes for each determination. A precision of 0.1 division corresponded to 0.01 and 0.003 percent, respectively, of the total volume. Calibrated weights were used and all weighings were corrected to vacuum.

The temperature of the solution in the picnometer was controlled in a clear Dewar flask or a silvered Dewar with a clear strip. At $+50^{\circ}$ and $+25^{\circ} \mathrm{C}$ water baths were used; at $0^{\circ} \mathrm{C}$, an ice and water bath; and at $-25^{\circ}$ and $-50^{\circ} \mathrm{C}$, alcohol cooled by the addition of small pieces of solid $\mathrm{CO}_{2}$. Except for the ice bath, a motordriven horizontal stirrer and a hand-operated vertical stirrer were used. The baths were maintained at the desired temperature for $20 \mathrm{~min}$ before measurements were taken. A series of five or more temperature and volume measurements were then made over a period of $15 \mathrm{~min}$ or longer. Temperature variations of $0.2 \mathrm{deg} \mathrm{C}$ introduced uncertainties in the densities of only 0.01 percent. Except at $-50^{\circ} \mathrm{C}$, the temperature was easily controlled to $0.2 \mathrm{deg}$, and the mean of a series of measurements was probably affected less than 0.01 percent by temperature variations. At $-50^{\circ} \mathrm{C}$, the temperature variations were somewhat larger but probably affected the density values by less than 0.05 percent. Temperatures above $-30^{\circ} \mathrm{C}$ were measured with calibrated mercury-in-glass thermometers with $0.1^{\circ}$ or $0.2^{\circ}$ divisions. At $-50^{\circ} \mathrm{C}$ a calibrated toluene thermometer with 
$1^{\circ}$ divisions was used. Corrections for the ambient temperature of the emergent stem were applied.

The composition of the solutions, expressed as percentage of $\mathrm{HClO}_{4}$ by weight, was determined by titrating two weighed portions of each solution, except for the 45-, 50-, and 55-percent-acid solutions. These three, together with the 40and 60-percent solutions, were made from the 70-percent-acid solutions by carefully weighed successive dilutions. Since the composition of the 40- and 60-percent solutions determined by titration differed from the composition calculated for the dilution by only 0.05 and 0.03 percent, respectively, the calculated compositions for the three intermediate solutions have been used. As a check on the acid contents determined by titration, the densities of the 45-, 50-, 55-, 60-, and 70-percent solutions were measured. The average difference between the acid contents determined by titration and by density measurements, using the values of Markham [1] ${ }^{2}$ and Smith and Goehler [2], was less than 0.03 percent acid, except for one solution. The acid contents as determined by titration were used in expressing the results of the measurements.

Chemical analyses of these two samples of commercial perchloric acid used in the work showed them to be of very high purity. These analyses are given below:

\begin{tabular}{|c|c|c|}
\hline Sample identification_..... & $\begin{array}{c}70 \text { to } 72 \% \text { of } \\
\mathrm{HClO}_{4}\end{array}$ & $60 \%$ of $\mathrm{HClO}_{4}$ \\
\hline Manufacturer & $\begin{array}{l}\text { G e n e r a l } \\
\text { Chemical } \\
\text { Co. }\end{array}$ & Baker \\
\hline $\begin{array}{l}\text { Assay } \\
\text { Nonvolatile matter } \\
\text { Chloride }(\mathrm{Cl}) \\
\text { Nitrogen compounds (as } \\
\mathrm{N} \text { ) } \\
\text { Sulfate }\left(\mathrm{SO}_{4}\right) \\
\text { Ammonia }\left(\mathrm{NH}_{3}\right) \\
\text { Heavy metals (limit } \\
\quad 0.0005 \% \text { of } \mathrm{Pb}) \\
\text { Iron }(\mathrm{Fe})\end{array}$ & $\begin{array}{cc}\text { Percent } & 70.9 \\
\text { Not }>0.000 \\
\text { Not }>.001 \\
\text { Not }>.004 \\
\text { Not }>.005 \\
\text { Not }>.001 \\
\\
\\
\\
\\
\\
\text { Passed } \\
\\
0.0002\end{array}$ & $\begin{array}{l}\text { Percent } \\
\quad 64 \\
\text { Not }>0.008 \\
\text { Not }>.0006 \\
\text { Not }>.002 \\
\text { Not }>.005 \\
\text { Not }>.0006 \\
\\
\\
\\
\quad .0005 \\
.0002\end{array}$ \\
\hline
\end{tabular}

Uncertainties in the composition may affect the density values by only 0.01 percent.

2 Figures in brackets refer to literature references at the end of this paper.

\section{(b) Measurements}

The densities of perchloric-acid solutions containing $9.69,19.72,29.17,40.01,44.97,49.95$, $54.95,60.00$, and 70.02 percent of $\mathrm{HClO}_{4}$, respectively, were measured at $+50^{\circ},+25^{\circ}, 0^{\circ}$, $-25^{\circ}$, and $-50^{\circ} \mathrm{C}$., the range of measurements of some solutions being limited, however, by their freezing points. Adjustments of the observed density values for the small differences of temperature from the even values given above were calculated from the temperature coefficients at each point. For each temperature the densities, in grams per milliliter, were plotted on large scale against the content of $\mathrm{HClO}_{4}$ (fig. 1). From these plots the densities for every 5 percent of $\mathrm{HClO}_{4}$ were read and smoothed by plots of the differences. These density values are given in table 1 . The values observed for the composition of the actual solutions are the points shown in figure 1 .

TABLE 1. Density of perchloric-acid solutions

\begin{tabular}{|c|c|c|c|c|c|}
\hline \multirow{2}{*}{$\begin{array}{l}\text { Percentage of } \mathrm{HClO}_{4} \\
\quad \text { (by weight) }\end{array}$} & \multicolumn{5}{|c|}{${ }^{\mathrm{a}}$ Density at - } \\
\hline & $+50^{\circ} \mathrm{C}$ & $+25^{\circ} \mathrm{C}$ & $0^{\circ} \mathrm{C}$ & $-25^{\circ} \mathrm{C}$ & $-50^{\circ} \mathrm{C}$ \\
\hline $0 \ldots$ & $\begin{array}{c}g / m l \\
\mathrm{~b}(0.9881)\end{array}$ & $\begin{array}{c}g / m l \\
\mathrm{~b}(0.9971)\end{array}$ & $\begin{array}{c}g / m l \\
\text { b }(0.9999)\end{array}$ & $g / m l$ & $g / m l$ \\
\hline 5 & 1.0150 & 1. 0257 & 1. 0308 & & \\
\hline 10 & 1.0437 & 1.0560 & 1. 0637 & & \\
\hline $15 \ldots$ & 1.0744 & 1.0882 & 1. 0986 & & \\
\hline $20 \ldots$ & 1. 1075 & 1. 1228 & 1.1356 & & \\
\hline 25 & 1.1433 & 1. 1600 & 1. 1749 & & \\
\hline $30 \ldots$ & 1. 1821 & 1. 2002 & 1. 2168 & 1. 2312 & \\
\hline $35 \ldots$ & 1. 2243 & 1. 2436 & 1. 2618 & 1. 2779 & \\
\hline $40 \ldots$ & 1. 2703 & 1. 2908 & 1. 3111 & 1. 3308 & 1. 3515 \\
\hline $45 \ldots$ & 1. 3205 & 1. 3428 & 1. 3657 & 1. 3893 & 1. 4140 \\
\hline $50 \ldots$ & 1. 3752 & 1. 3999 & 1. 4255 & 1. 4528 & \\
\hline $55_{\ldots} \ldots$ & 1. 4349 & 1.4615 & 1. 4897 & 1. 5203 & 1. 5590 \\
\hline $60 \ldots$ & 1.4994 & 1. 5275 & 1. 5580 & 1. 5908 & 1. 6300 \\
\hline $65 \ldots$ & 1. 5673 & 1. 5963 & 1. 6288 & 1. 6620 & (1. 696) \\
\hline $70 \ldots \ldots$ & 1. 6344 & 1. 6644 & 1. 6987 & 1. 7306 & \\
\hline
\end{tabular}

a The tabulated values are identical with those for the specific gravity referred to water at $4^{\circ} \mathrm{C}$.

b Values for water are from the International Critical Tables.

Since for the viscosity measurements of the perchloric-acid solutions, densities were needed at several temperatures in addition to those at which the densities were measured, large-scale plots of the data of table 1 were made of density versus 


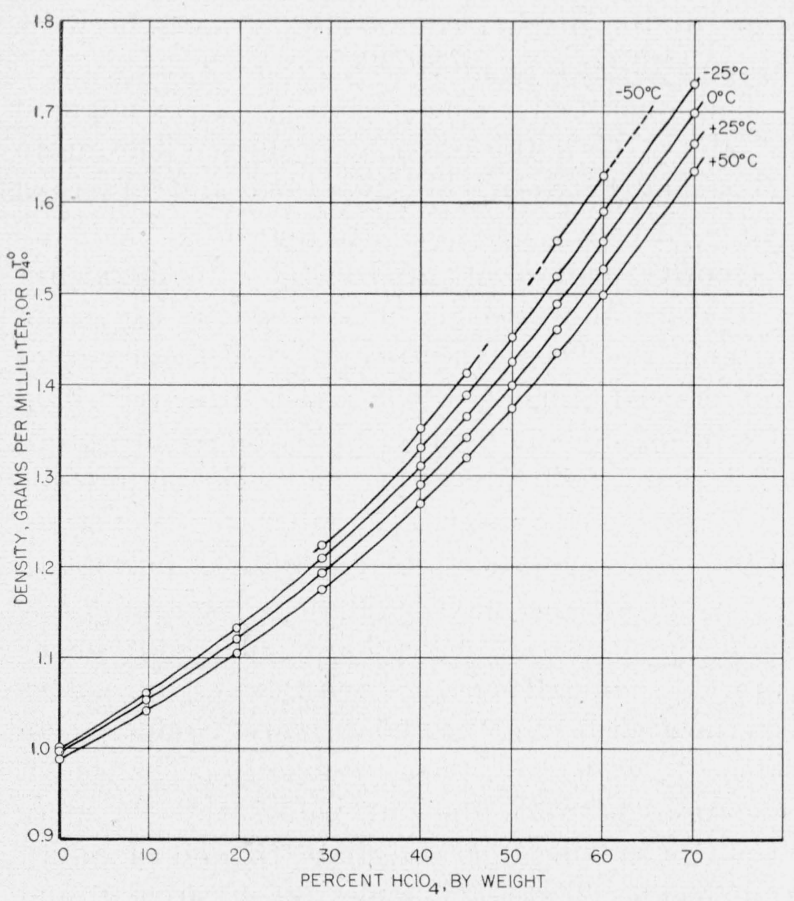

FIGURE 1. Isotherms of the density of perchloric-acid solutions.

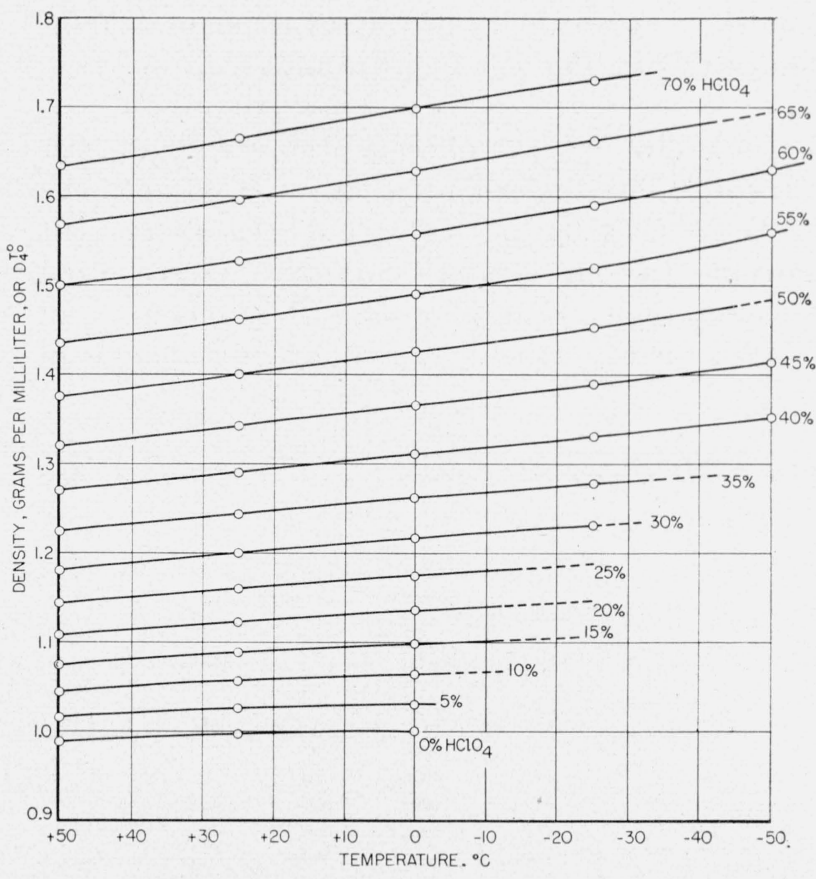

FIGURE 2. Density of perchloric-acid solutions as a function of temperature.

TABLE 2. Enlarged table of densities

(Values to more significant figures for certain temperatures are given in table 1)

\begin{tabular}{|c|c|c|c|c|c|c|c|c|c|c|c|c|c|c|c|}
\hline \multirow{2}{*}{ Percentage of $\mathrm{HClO}_{4}$} & \multicolumn{15}{|c|}{ Density at- } \\
\hline & $+50^{\circ} \mathrm{C}$ & $+40^{\circ} \mathrm{C}$ & $+30^{\circ} \mathrm{C}$ & $+25^{\circ} \mathrm{C}$ & $+20^{\circ} \mathrm{C}$ & $+15^{\circ} \mathrm{C}$ & $+10^{\circ} \mathrm{C}$ & $0^{\circ} \mathrm{C}$ & $-10^{\circ} \mathrm{C}$ & $-20^{\circ} \mathrm{C}$ & $-25^{\circ} \mathrm{C}$ & $-30^{\circ} \mathrm{C}$ & $-40^{\circ} \mathrm{C}$ & $-50^{\circ} \mathrm{C}$ & $-60^{\circ} \mathrm{C}$ \\
\hline 0 & $\begin{array}{l}g / m l \\
0.988\end{array}$ & $\begin{array}{l}g / m l \\
0.992\end{array}$ & $\begin{array}{l}g / m l \\
0.996\end{array}$ & $\begin{array}{l}g / m l \\
0.997\end{array}$ & $\begin{array}{l}g / m l \\
0.998\end{array}$ & $\begin{array}{l}g / m l \\
0.999\end{array}$ & $\begin{array}{l}g / m l \\
1.000\end{array}$ & $\begin{array}{l}g / m l \\
1.000\end{array}$ & $g / m l$ & $g / m l$ & $g / m l$ & $g / m l$ & $g / m l$ & $g / m l$ & $g / m l$ \\
\hline 5. & 1.015 & 1.020 & 1. 024 & 1. 026 & 1. 027 & 1.028 & 1. 029 & 1. 031 & - & & & & - & $-\infty$ & \\
\hline 10 & 1. 044 & 1. 050 & 1. 054 & 1. 056 & 1. 058 & 1. 060 & 1. 061 & 1.064 & $\mathrm{a}(1.066)$ & & & & & & \\
\hline $15 \ldots$ & 1. 074 & 1. 081 & 1. 086 & 1. 088 & 1.091 & 1. 093 & 1. 095 & 1.099 & 1. 102 & (1. 105) & & - & - & - & \\
\hline $20 \ldots$ & 1. 107 & 1.114 & 1. 120 & 1.123 & 1. 125 & 1. 128 & 1. 131 & 1. 136 & 1. 140 & (1.144) & & & & & \\
\hline 25. & 1.143 & $1.150_{5}$ & 1. 157 & 1. 160 & 1.163 & 1.166 & 1. 169 & 1.175 & 1. 180 & $\left(1.185_{5}\right)$ & (1. 189) & & & & \\
\hline 30. & 1. 182 & 1. 189 & $1.196_{5}$ & 1. 200 & 1. 204 & 1. 207 & 1. 210 & 1. 217 & 1. 223 & 1. $228_{5}$ & 1. 231 & (1. 233) & & & \\
\hline $35 \ldots$ & 1. 224 & 1. 232 & 1. $239_{5}$ & 1. 244 & 1. 247 & 1. 251 & 1. 255 & 1. 262 & 1. 268 & 1. 275 & 1. 278 & 1. 281 & (1. 286) & $\ldots$ & \\
\hline $40 \ldots$ & 1. 270 & 1. 278 & 1. 286 & 1. 291 & 1. $294_{5}$ & 1. $298_{5}$ & 1. 303 & 1.311 & 1. 318 & 1. $326_{5}$ & 1. 331 & 1. 335 & 1. 343 & 1.352 & \\
\hline $45 \ldots$ & 1.320 & 1.329 & 1. 338 & 1.343 & 1. 347 & 1. 352 & 1. 356 & 1.366 & 1.375 & 1. 384 & 1.389 & 1. 394 & 1. 404 & 1. 414 & \\
\hline 50. & 1.375 & 1. 385 & 1.395 & 1. 400 & 1.405 & 1. 410 & 1. 415 & 1.425 & 1. 436 & 1. 447 & 1. 453 & 1.459 & 1. 472 & (1. 484) & \\
\hline $55 \ldots$ & 1.435 & 1.445 & 1. $456_{5}$ & 1. 462 & 1.467 & 1. 473 & 1. 478 & 1.490 & 1. 502 & 1. 514 & 1.520 & 1. 527 & 1. 542 & 1. 559 & \\
\hline 60 & 1. 499 & 1. 510 & 1. $521_{5}$ & 1. $527_{5}$ & 1. 533 & 1. 539 & 1. 545 & 1. 558 & 1. 571 & 1. 584 & 1. 591 & 1. 598 & 1. 613 & 1. 630 & (1.647) \\
\hline $65 \ldots$ & 1. 567 & 1. 578 & 1. 590 & 1.596 & 1. 603 & 1. $609_{5}$ & 1. 616 & 1. 629 & 1. 643 & 1. 656 & 1. 662 & 1. 669 & $(1.682)$ & (1.696) & -........ \\
\hline 70 & 1. 634 & 1.645 & 1. 658 & 1. 664 & 1. 672 & 1. $678_{5}$ & 1. $685_{5}$ & 1. 699 & 1. $712_{5}$ & 1. 725 & . 1.731 & 1. 736 & 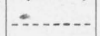 & . & ........ \\
\hline
\end{tabular}

a Values in parentheses are extrapolated and may represent solutions undercooled at the temperatures indicated.

temperature for each acid solution. From these plots, shown in figure 2 , the densities at intermediate temperatures were read. These data are given in table 2 .

\section{(c) Discussion of Results}

Some estimates of the uncertainties introduced into the measurements are discussed in section I, 2 (a) in connection with the description of the ap- 
paratus. For values at the experimental temperatures of $+50^{\circ},+25^{\circ}, 0^{\circ}$, and $-25^{\circ} \mathrm{C}$, i. e., those values given in table 1 (except for the 65percent solution), the uncertainties are about 0.01 percent. The uncertainties at $-50^{\circ} \mathrm{C}$ may be as large as 0.05 percent. For the 65-percent solution the uncertainties in the interpolated densities may be as great as 0.1 percent at all temperatures. This is caused by the change in

TABLE 3. Differences between smoothed (table 1) and observed values of densities

\begin{tabular}{|c|c|c|c|c|c|}
\hline \multirow{2}{*}{$\begin{array}{l}\text { Percentage of } \\
\mathrm{HClO}_{4} \text { (by } \\
\text { weight) }\end{array}$} & \multicolumn{5}{|c|}{ (smoothed-observed) at- } \\
\hline & $+50^{\circ} \mathrm{C}$ & $+25^{\circ} \mathrm{C}$ & $0^{\circ} \mathrm{C}$ & $-25^{\circ} \mathrm{C}$ & $-50^{\circ} \mathrm{C}$ \\
\hline & $g / m l$ & $g / m l$ & $g / m l$ & $g / m l$ & $g / m l$ \\
\hline $10 \ldots$ & -0.0001 & 0.0000 & -0.0001 & - n- & - n. \\
\hline $20 \ldots$ & .0000 & .0000 & .0000 & ...... & ...... \\
\hline $30 \ldots$ & -.0001 & -.0002 & -.0004 & -0.0002 & -.... \\
\hline $40 \ldots$ & +.0005 & +.0004 & +.0002 & -.0003 & -0.0004 \\
\hline $45 \ldots$ & .0000 & -.0001 & -.0002 & $+.00 \mathrm{u} 2$ & +.0004 \\
\hline $50 \ldots$ & +.0003 & -.0002 & -.0005 & -.0002 & -..... \\
\hline $55 \ldots$ & -.0008 & .0000 & .0000 & .0000 & -.0001 \\
\hline $60 \ldots$ & +.0002 & .0000 & .0000 & .0000 & +.0002 \\
\hline $70 \ldots$ & .0000 & .0000 & .0000 & +.0001 & ........ \\
\hline Mean ..... & $0.0002_{2}$ & 0.00010 & $0.0001_{6}$ & $0.0001_{4}$ & 0.0003 \\
\hline Deviation, \% & 0.017 & 0.007 & $0.01_{2}$ & $0.01_{0}$ & 0.019 \\
\hline
\end{tabular}

slope of the density-composition curves between 60- and 70-percent of $\mathrm{HClO}_{4}$.

The smoothed values (table 1) are compared in table 3 with the observed values. The mean deviations between the smoothed and observed values are only 0.01 to 0.02 percent.

Density values at intermediate temperatures needed for the viscosity measurements are given in table 2. These values were read from curves (reproduced in fig. 2) which justified the recording of four significant figures. The values are probably reliable to about 0.1 percent. The permissible uncertainty in density values for the calculation of the viscosity data is greater than 0.1 percent.

Several workers have previously reported a few values for densities of perchloric acid solutions at several temperatures. Their data, or values interpolated from their data, are compared in table 4 with our measurements. The mean deviations between the our values and the more recent ones, those of Markham [1] and of Smith and Goehler [2] at $+25^{\circ}$ and $+30^{\circ} \mathrm{C}$, are 0.01 and 0.02 percent. The deviations of our data from the older values, those of van Emster [3] at $+15^{\circ}$ and van $\mathrm{Wyk}[4]$ at $+50^{\circ} \mathrm{C}$, are somewhat larger, 0.05 and 0.2 percent, respectively. Except for the data of van Wyk, the agreement of the values is satisfactory.

TABLE 4. Comparison of NBS density values with previous determinations

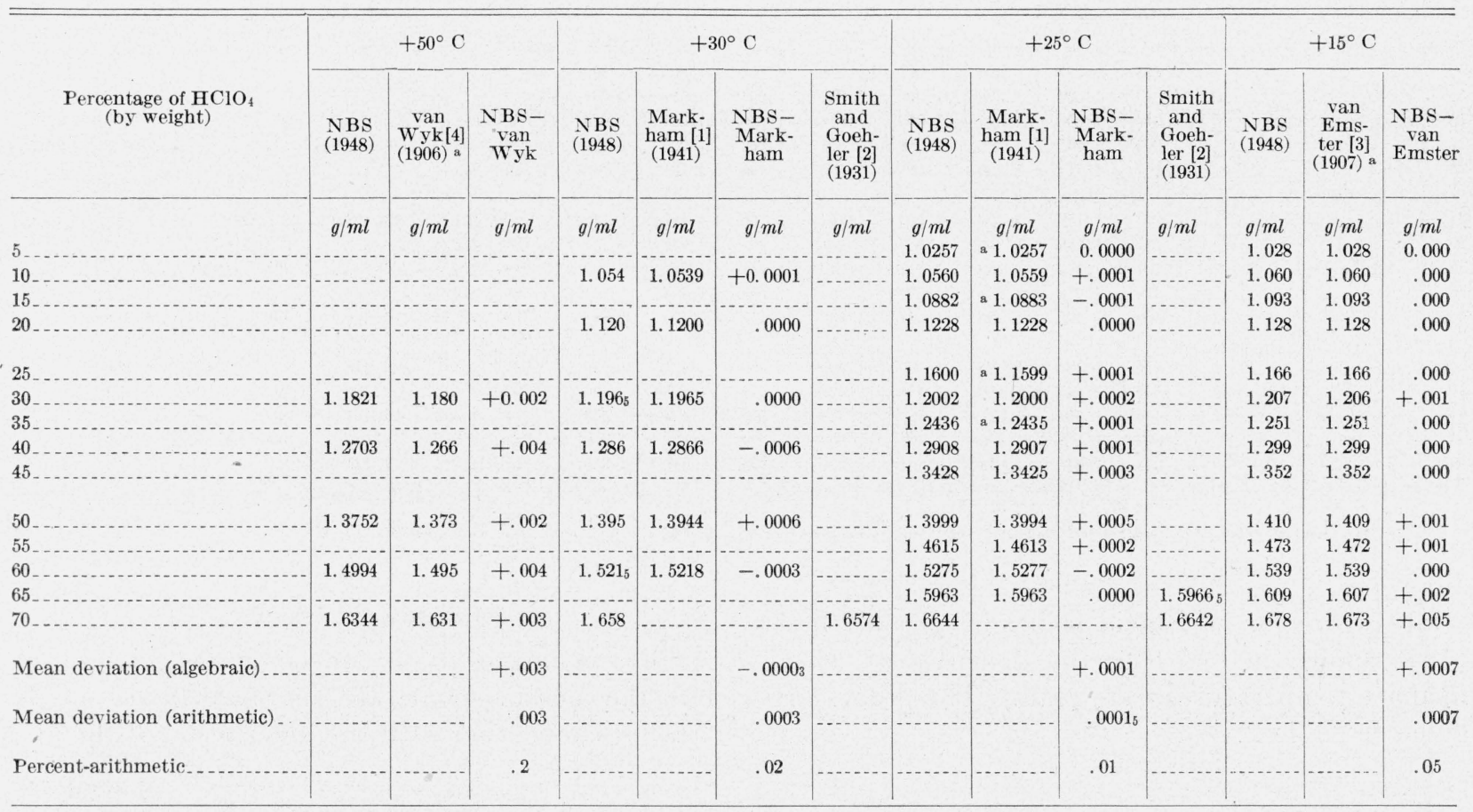




\section{(d) Summary}

Values for the density of perchloric-acid solutions at intervals of 5-percent composition by weight from 0 to 70 percent (except for $65 \%$ acid) are given at $+50^{\circ},+25^{\circ}, 0^{\circ}$, and $-25^{\circ} \mathrm{C}$ in table 1 with an uncertainty of about 0.01 percent. The values at $-50^{\circ} \mathrm{C}$ and all values for 65 -percent acid are given with an uncertainty of about 0.05 and $0.1 \%$, respectively.

Densities arrived at by graphical interpolation for a number of additional temperatures are given in table 2 with an uncertainty of about 0.1 percent.

\section{Viscosity \\ (a) Apparatus}

The perchloric-acid solutions and the means of controling and measuring temperatures were the same as for the density work.

The viscometers were the Fenske modification of the Ostwald type, as shown in figure 3. Three different instruments (sizes 50, 100, and 200) were used because of the wide variation in viscosity of the perchloric-acid solutions between $+50^{\circ}$ and $-60^{\circ} \mathrm{C}$. The instruments were calibrated by members of the staff of the Lubrication Section of this Bureau. Because of the high precision of the perchloric-acid measurements made with viscometers $50 / 74$ and $100 / 81$, special attention was given to calibrating these instruments by flow tests with water and aqueous solutions of sulfuric acid. Viscometer $200 / 284$ was calibrated by flow tests with oils of known viscosity. These calibrations were for:

1. Viscometer $50 / 74$, a calibration curve relating $\eta^{\prime} / t$ to $1 / t^{2}$.

2. Viscometer $100 / 81, \quad \eta^{\prime}=0.01592 t-0.638 / t$.

3. Viscometer $200 / 284, \eta^{\prime}=0.09076 t$.

$\eta^{\prime}$ is the kinematic viscosity of the liquid and $t$ is the corrected time of flow in seconds.

In all cases corrections were made to the observed time of flow to compensate for the effect of the difference between the surface tension of the perchloric-acid solution and the calibrating liquid, and for the effect of thermal expansion for temperatures other than the calibration temperature. Since surface tensions for perchloric acid solutions are not known, values were estimated from sul-

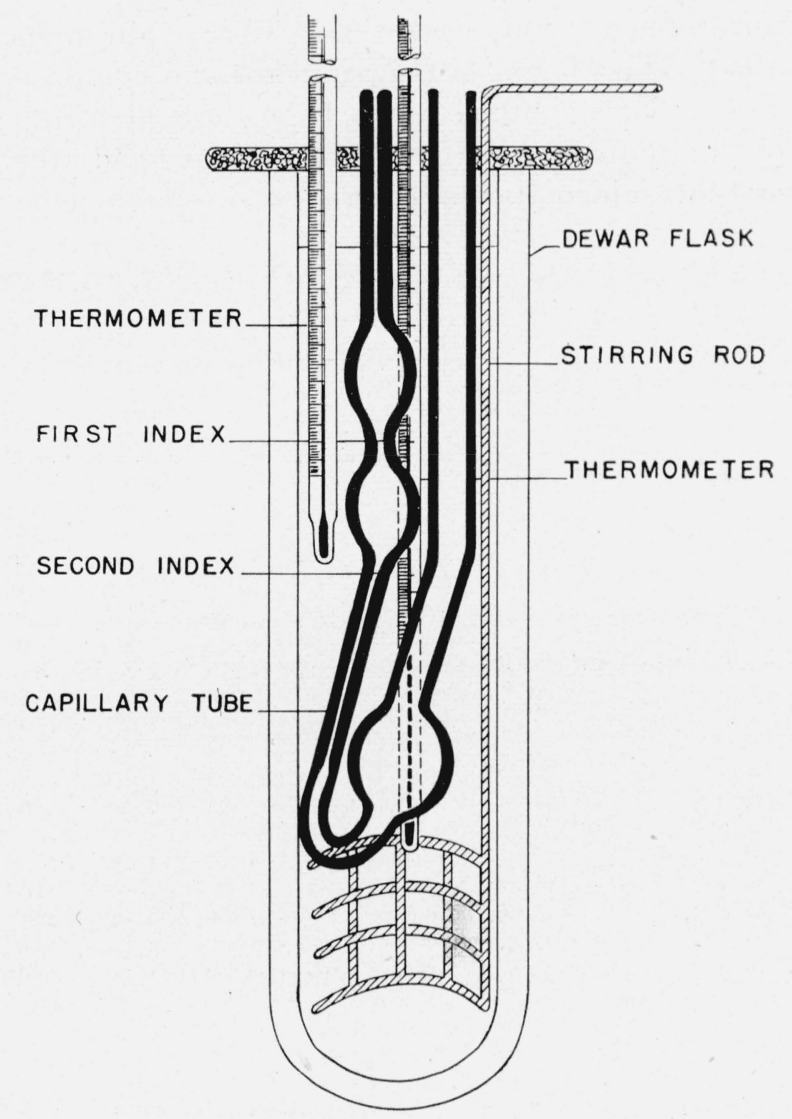

Figure 3. Fenske modification of Ostwald type viscometer.

furic acid solutions. This was sufficiently accurate because the compensations for surface-tension differences are small.

Times of flow of the acid solutions through the viscometers were measured with a calibrated stopwatch. They ranged from 1.5 to $45 \mathrm{~min}$.

All values of viscosity have been referred to the most probable value for the absolute viscosity of water at $20^{\circ} \mathrm{C}$ as given by Coe and Godfrey [5]. This value, $\eta_{\mathrm{H}_{2} \mathrm{O} \text { at } 20^{\circ} \mathrm{C}}$ is 1.002 centipoises.

\section{(b) Measurements}

Carefully standardized solutions, containing from 10 to 70 percent of $\mathrm{HClO}_{4}$ (referred to in section $\mathrm{I}, 2$, a) were investigated at $+25^{\circ} \mathrm{C}$ and at 10 -deg intervals from $+50^{\circ} \mathrm{C}$ to the freezing point of the solution. The kinematic viscosities were calculated and large scale plots were used to get values for even temperatures and even compositions.

The absolute viscosities were calculated for each experimental point by using densities interpolated 
from table 2. Large scale plots were again made to get values for even temperatures and compositions. The smoothed values from these plots and the absolute viscosities corresponding to the smoothed kinematic data were found to be in good agreement. The mean difference between the 138 pairs of values gotten from the two graphical treatments was less than 0.1 percent. The mean values are given in table 5 and the corresponding kinematic viscosities in table 6 .

TABLE 5. Absolute viscosity of perchloric-acid solutions

Based on absolute viscosity of water at $20^{\circ} \mathrm{C}=1.002$ centipoises

\begin{tabular}{|c|c|c|c|c|c|c|c|c|c|c|c|c|c|}
\hline \multirow{2}{*}{$\begin{array}{c}\text { Percentage of } \mathrm{HClO}_{4} \text { (by } \\
\text { weight) }\end{array}$} & \multicolumn{13}{|c|}{ Absolute viscosity, centipoises, at- } \\
\hline & $+50^{\circ} \mathrm{C}$ & $40^{\circ} \mathrm{C}$ & $30^{\circ} \mathrm{C}$ & $25^{\circ} \mathrm{C}$ & $20^{\circ} \mathrm{C}$ & $10^{\circ} \mathrm{C}$ & $0^{\circ} \mathrm{C}$ & $-10^{\circ} \mathrm{C}$ & $-20^{\circ} \mathrm{C}$ & $-30^{\circ} \mathrm{C}$ & $-40^{\circ} \mathrm{C}$ & $-50^{\circ} \mathrm{C}$ & $-60^{\circ} \mathrm{C}$ \\
\hline $0 \ldots$ & 0.547 & 0.653 & 0.798 & 0.890 & 1.002 & 1. 306 & 1.786 & 2. 59 & ...... & -..... & ...... & -.. & ..... \\
\hline $5 \ldots$ & .557 & .662 & .803 & .894 & 1.004 & 1. 287 & 1.743 & 2.47 & ..... & $\ldots$ & -...- & $\ldots$ & -.... \\
\hline $10 \ldots$ & .569 & .675 & .813 & .901 & 1.010 & 1. 280 & 1.714 & 2.40 & -.... & -...- & -.... & -...- & ..... \\
\hline $15 \ldots$ & .586 & .692 & .829 & .913 & 1.022 & 1. 286 & 1.701 & 2.347 & -..-. & -..-. & $\ldots$ & -.... & -.... \\
\hline $20 \ldots$ & .610 & .715 & .853 & .937 & 1.043 & 1.307 & 1.707 & 2.329 & -...- & -.... & ..... & ....- & -.... \\
\hline $25 \ldots$ & .641 & .750 & .890 & .974 & 1. 080 & 1. 347 & 1.745 & 2.353 & ..... & $\ldots$ & -... & ..... & .... \\
\hline $30 \ldots$ & .684 & .794 & .940 & 1. 031 & 1. 139 & 1. 413 & 1.815 & 2. 434 & 3. 415 & $\ldots$ & $\ldots$ & $\ldots$ & ..... \\
\hline $35 \ldots$ & .744 & .859 & 1.013 & 1. 108 & 1. 223 & 1.514 & 1.925 & 2. 572 & 3. 581 & $\ldots$ & -..... & $\ldots$ & ..... \\
\hline $40 \ldots$ & .822 & .950 & 1.118 & 1. 224 & 1. 345 & 1.670 & 2. 113 & 2.814 & 3.928 & 5.887 & 9.670 & 18. 21 & -.... \\
\hline $45 \ldots$ & .940 & 1.080 & 1. 274 & 1. 395 & 1. 534 & 1.900 & 2. 426 & 3.244 & 4. 582 & 7.139 & 11.96 & 23.13 & ....- \\
\hline $50 \ldots$ & 1. 099 & 1. 271 & 1. 507 & 1.650 & 1. 821 & 2. 268 & 2.914 & 3.962 & $\mathrm{a}(5.732)$ & 9.084 & 16.22 & ....... & -... \\
\hline $55_{\ldots}$ & 1. 329 & 1.548 & 1.837 & 2.022 & 2. 237 & 2. 819 & 3.677 & 5.104 & 7. 570 & 11.99 & 24.24 & 69.4 & .... \\
\hline $60 \ldots$ & 1. 646 & 1.928 & 2. 296 & 2. 532 & 2. 813 & 3. 560 & 4. 713 & 6. 700 & 9. 962 & 16. 25 & 34. 70 & $90.9_{5}$ & 345 \\
\hline $65 \ldots$ & 2. 076 & 2.440 & 2. 913 & 3.211 & 3.560 & 4.523 & 5. 969 & 8.40 & 12.37 & 19.88 & $\ldots$. & $\ldots$ & ..... \\
\hline $70_{\ldots} \ldots$ & 2. 639 & 3.094 & 3.692 & 4. 060 & 4. 504 & 5.675 & 7. 333 & 9.92 & 14.19 & 22.19 & -.... & -.... & $\ldots$ \\
\hline
\end{tabular}

a Vaine interpolated from curve.

TABLE 6. Kinematic viscosity of perchloric-acid solutions

\begin{tabular}{|c|c|c|c|c|c|c|c|c|c|c|c|c|c|}
\hline \multirow{2}{*}{$\begin{array}{c}\text { Percentage of } \mathrm{HClO}_{4} \text { (by } \\
\text { weight) }\end{array}$} & \multicolumn{13}{|c|}{ Kinematic viscosity, centistokes, at- } \\
\hline & $+50^{\circ} \mathrm{C}$ & $40^{\circ} \mathrm{C}$ & $30^{\circ} \mathrm{C}$ & $25^{\circ} \mathrm{C}$ & $20^{\circ} \mathrm{C}$ & $10^{\circ} \mathrm{C}$ & $0^{\circ} \mathrm{C}$ & $-10^{\circ} \mathrm{C}$ & $-20^{\circ} \mathrm{C}$ & $-30^{\circ} \mathrm{C}$ & $-40^{\circ} \mathrm{C}$ & $-50^{\circ} \mathrm{C}$ & $-60^{\circ} \mathrm{C}$ \\
\hline $0 \ldots$ & 0.554 & 0.658 & 0.801 & 0.893 & 1.004 & 1.306 & 1.786 & 2. 59 & ...... & -.... & $\ldots$ & ...... & ...... \\
\hline $5 \ldots$ & .549 & .649 & .784 & .871 & 0.978 & 1. 251 & 1.691 & 2.40 & $\ldots$ & $\ldots$ & $\ldots$ & $\ldots$ & $\ldots$ \\
\hline $10 \ldots$ & .545 & .643 & .771 & .853 & .955 & 1.206 & 1.611 & 2.25 & ...... & -.... & -.... & ...... & ..... \\
\hline $15 \ldots$ & .546 & .640 & .763 & $.839_{5}$ & .937 & 1.174 & 1.548 & 2. 130 & $\ldots$ & $\ldots$ & $\ldots$ & $\ldots$ & $\ldots$ \\
\hline 20 & .551 & .642 & .762 & .834 & .927 & 1. 156 & 1. 503 & 2.043 & $\cdots$ & $\ldots$ & $\cdots$ & -...- & $-\ldots$ \\
\hline 25 & .561 & .652 & .769 & .840 & .929 & 1.152 & 1.485 & 1.994 & & $\ldots$ & $\ldots$ & $\ldots$ & $\ldots . .$. \\
\hline 30 & .579 & .668 & .786 & .859 & .946 & 1.168 & 1.491 & 1.990 & 2.78 & $\cdots$ & - & -... & - n plo \\
\hline $35 \ldots$ & .608 & .697 & $.817_{5}$ & .891 & .981 & 1. $206_{5}$ & 1. 525 & 2. 028 & 2. 809 & $\ldots$ & $\ldots$ & $\ldots$ & $\ldots$ \\
\hline $40 \ldots$ & .647 & .743 & .869 & .948 & 1.039 & 1.282 & 1.612 & 2.135 & 2. 961 & 4.410 & 7. 20 & 13.47 & ..... \\
\hline $45 \ldots$ & .712 & .813 & .952 & 1. 039 & 1. 139 & 1.401 & 1. 776 & 2.359 & 3. 311 & 5. 121 & 8. 52 & 16. 36 & ..... \\
\hline 50. & .799 & .918 & 1. 080 & 1. $178_{5}$ & 1. 296 & 1.603 & 2.045 & 2. 759 & a (3. 961) & 6.226 & 11. 02 & ..... & -....- \\
\hline $55 \ldots$ & .926 & 1.071 & 1. 261 & 1.383 & 1. 525 & 1.907 & 2. 468 & 3.398 & 5. 000 & 7.852 & 15. 72 & 44.5 & $\ldots$ \\
\hline $60 \ldots$ & 1.098 & 1. 277 & 1.509 & 1. $657_{5}$ & 1. 835 & 2.304 & 3. 025 & 4. 265 & 6. 289 & 10.17 & 21.51 & 55.8 & 209 \\
\hline $65 \ldots$ & 1.325 & 1. 546 & 1.832 & 2. 012 & 2. 221 & 2. 799 & 3.664 & 5.11 & 7.47 & 11.91 & ..... & ..... & 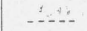 \\
\hline $70 \ldots \ldots$ & 1.615 & 1.881 & 2. 227 & 2. 440 & 2. 694 & 3.367 & 4. 316 & 5. 79 & 8. 227 & 12. 78 & ..... & -... & -.... \\
\hline
\end{tabular}

a Value interpolated from curve.

The relation of the viscosity to temperature is shown by graphs of the observed points for each solution in figure 4 . The viscosity rises with decreasing temperature for all solutions. The rise is especially rapid at low temperatures for the solutions of higher $\mathrm{HClO}_{4}$ content.
The isotherms relating viscosity to $\mathrm{HClO}_{4}$ content are shown in figure 5 . In general, the viscosity rises as the $\mathrm{HClO}_{4}$ content of the solution increases. This rise is especially rapid at the lower temperatures and for the more concentrated solutions. At temperatures below $+20^{\circ} \mathrm{C}$, how- 


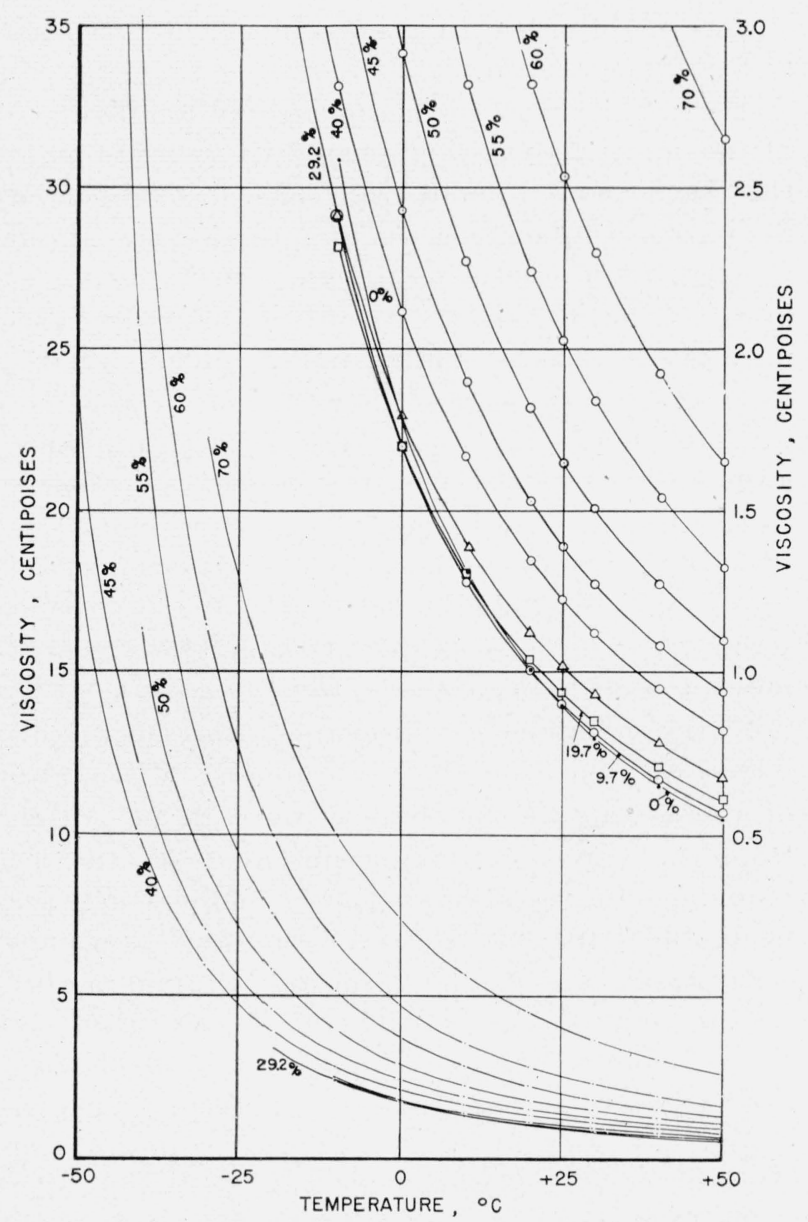

Figure 4. Viscosity of perchloric-acid solutions as a function of temperature. ever, there are minima in the curves between 5 and 20 percent of $\mathrm{HClO}_{4}$. A redetermination of some points, in some cases with a different viscometer, has definitely established the existence of minima in this region.

The inflections of the low-temperature isotherms at the higher acid compositions are interesting. The shapes of the curves suggest that the viscosities may go through maxima for solutions of compositions higher than those with which we worked. Even for a temperature as high as $+50^{\circ} \mathrm{C}$, van Wyk has reported a maximum in viscosity for a composition of about 80 percent of $\mathrm{HClO}_{4}$ by weight. van Wyk's data showing the maximum are given in table 7 [6].

\section{(c) Accuracy}

The experimental determinations plotted in figure 4 are the averages of repeated measurements; usually from three to six discharges were made for each point. Smooth curves were passed through the 95 experimental points except for two cases (70-percent solution at $+30^{\circ}$ and $-30^{\circ}$ C), where the deviations of the plotted points from the curve are about 0.3 percent. Graphical treatments of the data both as kinematic viscosities and as absolute viscosities were carried out. The mean of the differences between the absolute viscosities arrived at in these two ways was less than 0.1 percent over the whole range of tem-

TABLE 7. Comparison of NBS values with determination of van Wyk

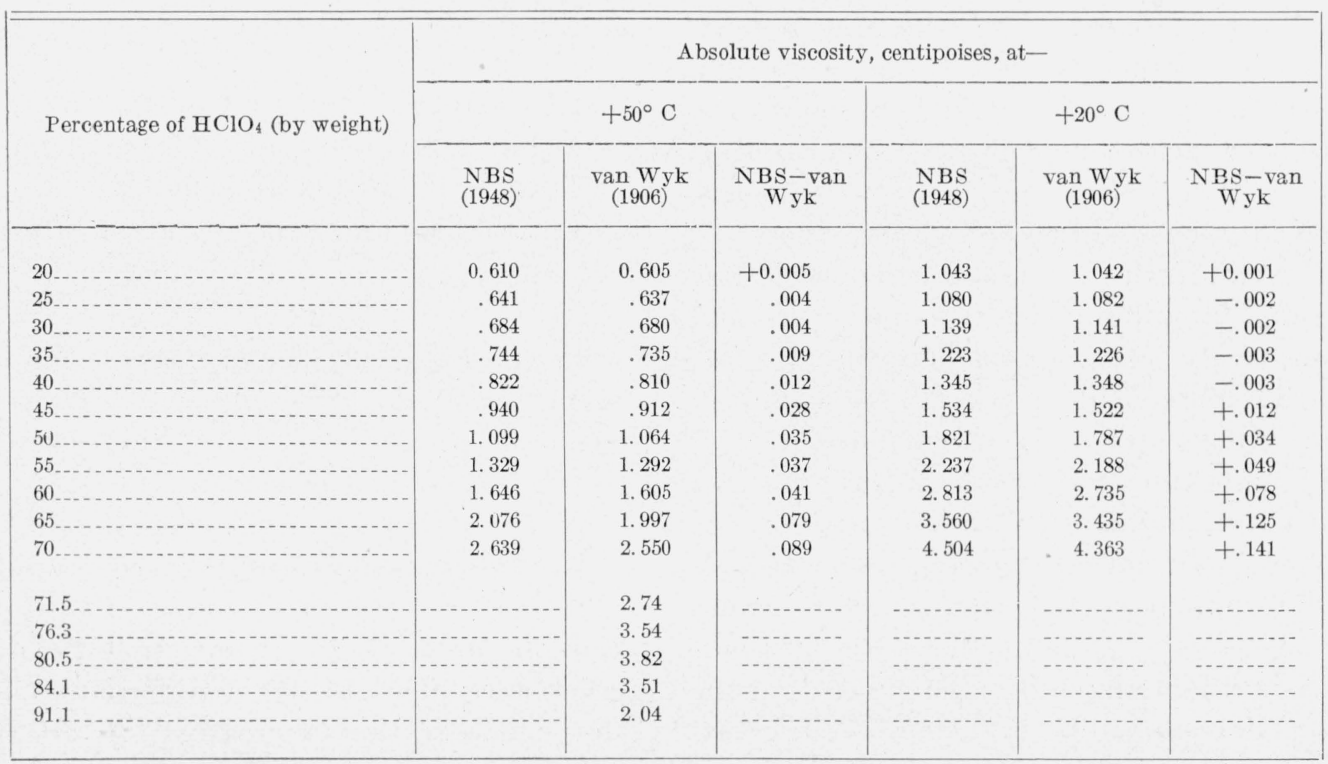




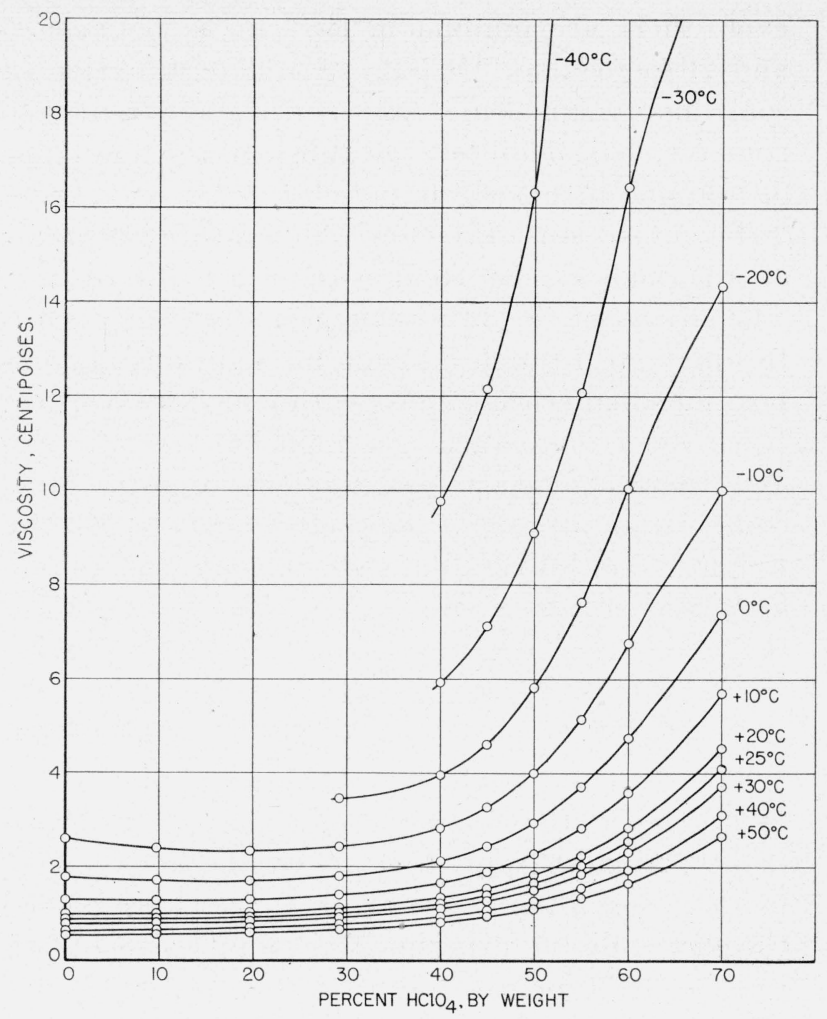

Figure 5. Isotherms of the viscosity of perchloric-acid solutions.

peratures and solutions. The maximum difference for any point was only 0.7 percent.

The measurements are subject to systematic errors from several sources. Attempts were made to eliminate systematic errors introduced by uncertainties in the constants of the viscometers. The No. 50 and No. 100 viscometers were calibrated with water and sulfuric-acid solutions. Three perchloric-acid solutions were measured at the ice point with each of these instruments. These measurements differed by less than 0.3 percent. Uncertainties in estimating the time compensations for differences in temperature and surface tension are less than 0.1 percent

Systematic errors in determining the composition of the solutions have been avoided as far as possible by checking the results of the weight titrations by measurements of the specific gravity. Except for one solution, differences in the composition as determined by the two methods would affect the viscosity by less than 0.1 percent. All the measurements have been calculated on the compositions determined by titration. Mean var- iations of duplicate titrations affect the viscosity by only 0.04 percent.

Accidental errors in measuring the temperature of the solutions were minimized by repetitions of the discharges. Usually from three to six repeated discharges were made at each temperature. From the higher temperatures through $-30^{\circ} \mathrm{C}$, mercuryin-glass thermometers with $0.1^{\circ}$ or $0.2^{\circ}$ divisions were used. The estimated uncertainty is $\pm 0.02^{\circ}$ or \pm 0.07 percent or less above $-1^{\circ} \mathrm{C}$; and somewhat larger at $-10^{\circ},-20^{\circ}$, and $-30^{\circ} \mathrm{C}$, probably approaching $\pm 0.1^{\circ} \mathrm{C}$ or \pm 0.5 percent in viscosity. At $-40^{\circ},-50^{\circ}$, and $-60^{\circ} \mathrm{C}$, spirit thermometers of $1^{\circ} \mathrm{C}$ divisions were used. In this range the uncertainty is probably \pm 0.1 or $\pm 0.2^{\circ} \mathrm{C}$, corresponding to an uncertainty of as much as 2 or 3 percent in viscosity.

Errors in timing the discharges were also minimized by repeating the experiments. Estimates of the magnitude of these errors can be gotten from the variations in measurements at the ice point where variations of the temperature are negligible. In only three of the nine measurements at $0^{\circ} \mathrm{C}$ was the variation as great as 0.1 sec for repeated runs. Therefore, we may say that accidental errors of timing even the fastest discharges were less than 0.1 percent. Instrumental errors introduced from the calibration of the watch were of the same order of magnitude.

The NBS density values used in computing the absolute viscosities were uncertain by about 0.1 percent or less.

In conclusion, the uncertainty of all values given in tables 5 and 6 is

1. For $0^{\circ}$ to $+50^{\circ} \mathrm{C}$, less than 0.5 percent.

2. For $-10^{\circ}$ to $-30^{\circ} \mathrm{C}, 0.5$ to 1.0 percent.

3. At $-40^{\circ} \mathrm{C}$, about 2 percent.

4. At $-50^{\circ}$ and $-60^{\circ} \mathrm{C}$, about 3 percent.

\section{(d) Comparison with Previous Determinations}

In the range of special interest for the present work, i. e. at the lower temperatures, no data were available in the literature. There were, however, some viscosity measurements at $+50^{\circ}$ and $+20^{\circ}$ $\mathrm{C}$ made in 1906 by van Wyk [6].

In table 7, values interpolated graphically from van Wyk's data are compared with our data. For the more dilute solutions, the data are in good agreement, but the differences increase as the concentration increases. At 70 percent of 
$\mathrm{HClO}_{4}$, our measurements differ from van Wyk's by 3 percent. This difference is greater than the estimated uncertainty, but probably not greater than the uncertainty of the earlier work.

In table 7 are also given some of van Wyk's measurements for solutions above 70 percent. These are included to show that the curves of viscosity versus composition go through maxima at high compositions. The present data, which cover the range up to 70 percent of $\mathrm{HClO}_{4}$ show inflections at the lower temperatures and suggest the existence of maxima.

\section{Electrical Resistivity}

\section{(a) Apparatus}

The electrical bridge used was especially suited to measurements of electrolytic resistances. The authors are indebted to $\mathrm{F}$. Wenner, formerly of this Bureau, for his assistance in planning the bridge. It consisted of two equal ratio arms having resistances of $10 \mathrm{ohms}$. The third arm was a decade resistance box with 0.1-ohm steps in the last dial. Between this and the fourth arm, i. e., the cell arm, there was a slide wire by means of which continuous resistance settings could be made. After each balance of the bridge with the cell, a high-precision noninductive decade resistor was substituted directly for the cell. This substitution method of determining the cell resistance eliminated errors from several sources. The potential applied to the bridge was $0.5 \mathrm{v}$ at 1,000 cycles per second. The heating effect of the current was negligible, as shown by the fact that the change in resistance of the cell was less than 0.05 percent after a continuous flow of the current through the cell for $\frac{1}{2} \mathrm{hr}$. Ordinarily a measurement was completed within a minute or two after the bridge circuit was closed.

The detector circuit consisted of a vacuum-tube booster amplifier and telephones. The telephone detector circuit was coupled to the bridge circuit by a small mutual inductor which permitted balancing any out-of-phase component of potential difference in the bridge. Resistance measurements could be repeated to 0.01 percent except for the highest values, where the precision was 0.04 percent.

Two conductivity cells having, respectively, cell-constants of $73.45_{9}$ and $17.66_{9}$ at $25^{\circ} \mathrm{C}$ were employed. A Parker solution of $76.627_{6} \mathrm{~g}$ of purified potassium chloride per kilogram of distilled water was used for determining the constants. The difference in resistivity of several perchloric-acid solutions measured with both cells was in each case less than the estimated experimental error from other sources.

The temperature was controlled by immersing the cell in a Dewar flask containing an alcohol or water bath. The flask was covered with two layers of cork and was provided with a stirrer.

For each resistance measurement the temperature of the cell was measured by two liquid-in-glass thermometers with their bulbs placed close to the center of the conductivity cell. The temperatures were read through a telescope, and corrections for scale readings and for emergent-stem temperatures were applied to the readings. For temperatures above $-38^{\circ} \mathrm{C}$ mercury thermometers graduated to $0.1^{\circ}$ or $0.2^{\circ} \mathrm{C}$ were used. For temperatures below $-38^{\circ} \mathrm{C}$, toluene thermometers graduated in centigrade degrees, and mercury-thallium-alloy thermometers graduated to $0.5^{\circ} \mathrm{F}$ (about $0.3^{\circ} \mathrm{C}$ ) were used. The solutions were the same as those for the density and viscosity measurements.

\section{(b) Experimental Results}

The resistance of each solution was measured at 10-deg intervals from $+50^{\circ} \mathrm{C}$ down to the freezing temperature of the solution. Each solution was measured at each temperature from two to eight times. The individual observations were plotted on large scales, and the weighted mean values were determined. Resistivities, calculated from the mean resistances, were then plotted with respect to temperature for each solution. Resistivities at 10 -deg intervals, with the addition of values for $+15^{\circ}$ and $+25^{\circ} \mathrm{C}$, were read from the curves. By using these resistivity values, isothermal curves for resistivity have been plotted against percentage composition of acid. These curves are shown in figure 6 .

Table 8 gives the complete results of our measurements. The values of table 8 were read in part from the large scale plots of figure 6 , in part from sectional plots made on a larger scale for low resistivities, and from semilogarithmic plots for resistivities above $20 \mathrm{ohm}-\mathrm{cm}$. 
TABLE 8. Resistivity of perchloric-acid solutions

\begin{tabular}{|c|c|c|c|c|c|c|c|c|c|c|c|c|c|}
\hline \multirow{2}{*}{ Temperature } & \multicolumn{13}{|c|}{ Percentage of perchloric acid- } \\
\hline & 10 & 15 & $20 *$ & 25 & 30 & 35 & 40 & 45 & 50 & 55 & 60 & 65 & 70 \\
\hline${ }^{\circ} \mathrm{C}$ & Ohm-cm & Ohm-cm & Ohm-cm & Ohm-cm & Ohm-cm & Ohm-cm & Ohm-cm & Ohm-cm & Ohm-cm & $\mathrm{Ohm}-\mathrm{cm}$ & Ohm-cm & Ohm-cm & Ohm-cm \\
\hline$+50 \ldots$ & 2. 207 & 1. 580 & 1.272 & 1.106 & 1.028 & 0.990 & 1.001 & 1. 056 & 1.154 & 1.313 & 1.540 & 1.903 & 2. 401 \\
\hline$+40 \ldots$ & 2. 428 & 1. 730 & 1.397 & 1. 219 & 1. 132 & 1.095 & 1. 106 & 1. 169 & 1. 286 & 1. 470 & 1.725 & 2. 124 & 2. 704 \\
\hline$+30 \ldots$ & 2. 715 & 1. 933 & 1.562 & 1.362 & 1. 262 & 1. 222 & 1. 240 & 1. 314 & 1. 452 & 1. 668 & 1.961 & 2.417 & 3.084 \\
\hline$+25 \ldots$ & 2.898 & 2. 064 & 1.665 & 1. 451 & 1. 344 & 1. 301 & 1. 320 & 1. 405 & 1. 551 & 1. 792 & 2. 106 & 2. 598 & 3.314 \\
\hline$+20 \ldots$ & 3.100 & 2. 200 & 1. 776 & 1. 551 & 1. 436 & 1. 393 & 1. 414 & 1. 502 & 1. 670 & 1.928 & 2. 275 & 2. 776 & 3.575 \\
\hline+15 & 3. 342 & 2. 359 & 1. 906 & 1. 670 & 1. 547 & 1. 499 & 1. 525 & 1. 626 & 1. 809 & 2. 102 & 2. 482 & 3.040 & 3.876 \\
\hline$+10 \ldots$ & 3.628 & 2. 532 & 2.072 & 1.809 & 1. 665 & 1. 616 & 1. 647 & 1. 757 & 1. 964 & 2. 286 & 2. 705 & 3.372 & 4. 227 \\
\hline $0 \ldots$ & 4.420 & 3.095 & 2. 488 & 2. 169 & 1. 992 & 1.920 & 1. 968 & 2. 111 & 2. 376 & 2. 792 & 3.320 & 4.120 & 5. 129 \\
\hline$-10 \ldots$ & - . & $a(3.70)$ & 3.102 & 2. 681 & 2. 464 & 2. 384 & 2. 436 & 2. 622 & 2. 982 & 3.551 & 4. 242 & 5. 24 & 6.418 \\
\hline$-20 \ldots$ & ..... & -....... & ..... & $\ldots$ & 3.176 & 3.076 & 3. 133 & 3.396 & 3.919 & 4.755 & 5. 742 & 6.97 & 6.395 \\
\hline-30 & -... & -... & $\ldots$ & ..... & ..... & $(4.25)$ & 4. 250 & 4. 657 & 5. 505 & 6.869 & 8.402 & 9.98 & 11.59 \\
\hline$-40 \ldots$ & $\ldots$ & $\ldots$ & $\ldots$ & $\ldots$ & $\ldots$ & $(6.17)$ & 6.21 & 6.88 & 8.44 & 11.11 & 13.82 & ..... & .... \\
\hline-50 & $\ldots$ & $\ldots$ & .... & - . & -... & ..... & 10.41 & 12.02 & -... & 22.6 & 27.1 & ..... & .... \\
\hline$-60 \ldots \ldots$ & -.... & $\ldots$ & $\ldots$ & $\ldots$ & $\ldots$ & -.... & ..... & $\ldots$ & $\ldots$ & . & 76.8 & ..... & $\ldots$ \\
\hline
\end{tabular}

a Values given in parentheses are extrapolated.

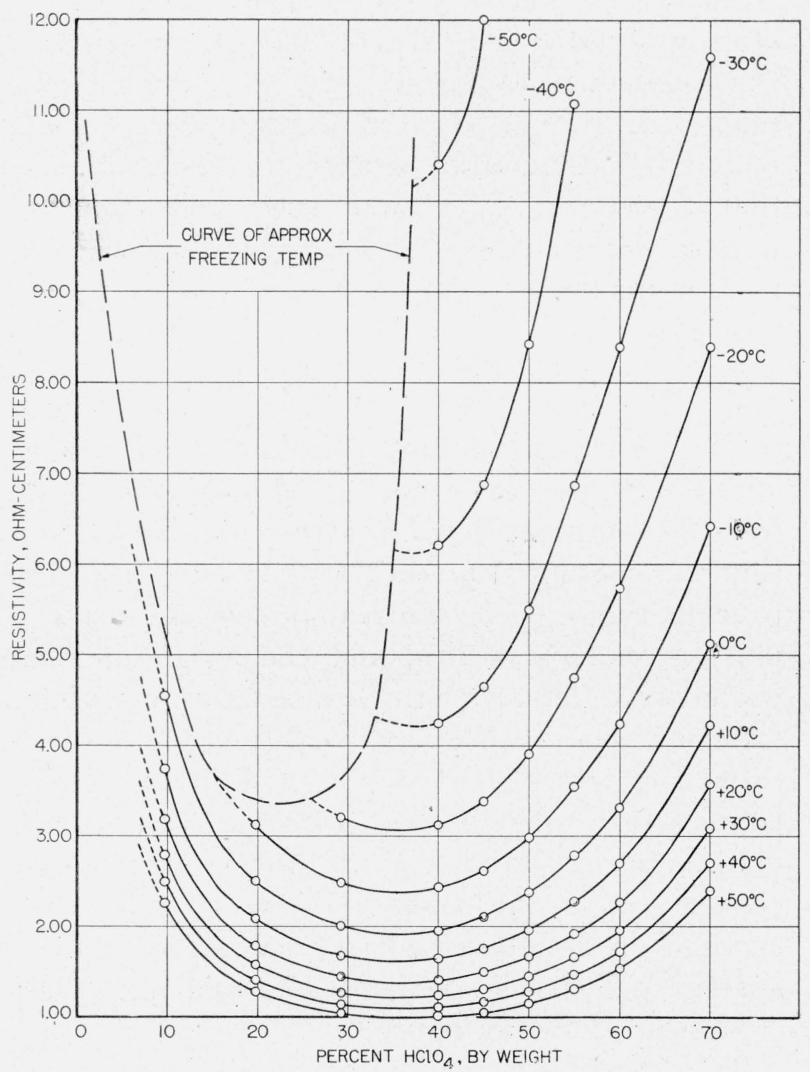

Figure 6. Resistivity of perchloric-acid solutions.

(c) Accuracy of Measurements

Several experimental errors were discussed in connection with the description of the apparatus in section $I, 4$ (a). These uncertainties in the measurements were less than 0.05 percent.
Uncertainties in the determination of the acid content of the solutions did not affect the resistivity values by more than 0.06 percent in any solution.

The greatest uncertainties were introduced by the variations and measurements of temperature. From $-30^{\circ}$ to $+50^{\circ} \mathrm{C}$ uncertainties due to temperature were probably 0.1 percent or less. At $-40^{\circ} \mathrm{C}$ the uncertainty introduced by the temperature was from 0.5 to 1 percent, and at $-50^{\circ}$ and $-60^{\circ} \mathrm{C}$ it was probably between 1 and 2 percent.

Interpolated values read from carefully drawn curves for all observations above $-30^{\circ} \mathrm{C}$ probably are not in error by more than 0.1 percent in the vicinity of the plotted points. Intermediate values read from the curves, however, may be subject to greater errors, but these are quite certainly less than 0.5 percent. In the following tabulation an estimate of the errors from all sources is given for the various parts of the work.

In conclusion, the uncertainty of values given in table 8 for points in the vicinity of the experimental values are

1. For $-30^{\circ}$ to $+50^{\circ} \mathrm{C}$, not more than 0.1 percent (except for the 10-percent solution at $\left.0^{\circ} \mathrm{C}\right)$.

2. At $-40^{\circ} \mathrm{C}$, less than 1 percent.

3. At $-50^{\circ}$ and $-60^{\circ} \mathrm{C}$, less than 2 percent. Values intermediate between the experimental values are probably not uncertain by more than 0.5 percent. These are the values given in table 
8 for $+15^{\circ}$ and $+25^{\circ} \mathrm{C}$ and for $15-, 25-, 35-$, and 65 -percent-acid solutions.

\section{Relation Between Resistivity, Kinematic Viscosity, and Temperature}

Vinal and Craig [7] found in their work on the resistivity and viscosity of sulfuric-acid solutions an interesting empirical relation connecting these properties with the absolute temperature, $T$. They found that

$$
\frac{\log (20 \times \text { kinematic viscosity })}{\sqrt{T} \log (6 \times \text { resistivity })}=K=0.100 .
$$

The constant $K$ was found to be 0.100 (average deviation of only 1 percent) for 28- to 45-percent $\mathrm{H}_{2} \mathrm{SO}_{4}$ solutions, and extending over the temperature range of their work, $-40^{\circ}$ to $+30^{\circ} \mathrm{C}$.

The kinematic viscosity' and resistivity of perchloric acid solutions are related by a function of the same form

$$
\frac{\log (20 \times \text { kinematic viscosity })}{\sqrt{\mathrm{T}} \log (4 \times \text { resistivity })}=K=0.100,
$$

for solutions varying from 30 to 60 percent of $\mathrm{HClO}_{4}$ and over the temperature range $-50^{\circ}$ to $+50^{\circ} \mathrm{C}$.

The values of $K$ for each $\mathrm{HClO}_{4}$ solution are given in table 9 . From the table it can be seen that values of $K$ for the 10-, 20-, and 70-percent $\mathrm{HClO}_{4}$ solutions are not constant with respect to either temperature or concentration. Over the range of compositions where the relation does apply, i. e., 30 to 60 percent of acid, the average deviation is 1.8 percent. Over the entire range of the solutions, the average deviation is 6.7 percent.

It is interesting that the same type of function applies to concentrated solutions of sulfuric and perchloric acids and that the value of $K$ is essentially 0.1 for both acids.

In table 9 are also given values for the log functions used in calculating $K$. These are included for convenience in finding intermediate values of resistivity and viscosity. The reciprocals of these $\log$ functions are nearly linear relations of the temperature and composition.
TABLE 9. Relation between resistivity, kinematic viscosity,

\begin{tabular}{|c|c|c|c|c|c|c|}
\hline \multirow{2}{*}{$\mathrm{HClO}_{4}$} & & \multicolumn{2}{|c|}{ Temperature } & \multirow{2}{*}{$\begin{array}{c}\log \\
(20 \times k i n e- \\
\text { matic vis- } \\
\text { cosity) }\end{array}$} & \multirow{2}{*}{$\begin{array}{c}\log \\
\text { (4Xresis- } \\
\text { tivity) }\end{array}$} & \multirow{2}{*}{$K$} \\
\hline & & $T$ & $\sqrt{T}$ & & & \\
\hline \multirow[t]{4}{*}{ Percent } & ${ }^{\circ} C$ & $\circ A b s$ & $\left({ }^{\circ} \boldsymbol{A} b s\right)^{1 / 2}$ & & & \\
\hline & $(+50$ & 323.16 & 17.98 & 1. 0374 & 0.9459 & 0.0610 \\
\hline & 40 & 313.16 & 17.70 & 1. 1092 & .9873 & .0635 \\
\hline & 30 & 303.16 & 17.41 & 1. 1881 & 1. 0358 & .0659 \\
\hline \multirow{3}{*}{$10 \ldots$} & 20 & 293.16 & 17.12 & 1. 2810 & 1. 0934 & .0684 \\
\hline & 10 & 283.16 & 16.83 & 1. 3824 & 1. 1617 & .0707 \\
\hline & 0 & 273.16 & 16.53 & 1. 5081 & 1. 2475 & .0731 \\
\hline \multirow{7}{*}{$20 \ldots \ldots$} & 50 & 323.16 & 17.98 & 1. 0422 & 0. 7066 & .0820 \\
\hline & 40 & 313.16 & 17. 70 & 1. 1086 & .7473 & .0838 \\
\hline & 30 & 303.16 & 17.41 & 1. 1830 & .7957 & .0854 \\
\hline & 20 & 293.16 & 17.12 & 1. 2681 & .8515 & .0870 \\
\hline & 10 & 283.16 & 16. 83 & 1. 3640 & .9184 & .0882 \\
\hline & 0 & 273.16 & 16.53 & 1.4780 & .9979 & .0896 \\
\hline & -10 & 263.16 & 16. 22 & 1. 6113 & 1. 0937 & .0908 \\
\hline \multirow{8}{*}{$30 \ldots$} & $\int+50$ & 323.16 & 17.98 & 1. 0637 & 0.6140 & .0963 \\
\hline & 40 & 313.16 & 17. 70 & 1. 1258 & .6559 & .0970 \\
\hline & 30 & 303.16 & 17.41 & 1. 1964 & .7031 & .0977 \\
\hline & 20 & 293. 16 & 17.12 & 1. 2769 & .7592 & .0982 \\
\hline & 10 & 283.16 & 16.83 & 1. 3685 & .8235 & .0987 \\
\hline & 0 & 273.16 & 16.53 & 1. 4745 & .9014 & .0990 \\
\hline & -10 & 263.16 & 16. 22 & 1. 5999 & .9937 & .0993 \\
\hline & -20 & 253.16 & 15.91 & 1. 7451 & 1. 1039 & .0994 \\
\hline \multirow{11}{*}{$40 \ldots$} & +50 & 323.16 & 17.98 & 1. 1119 & 0.6025 & .1026 \\
\hline & 40 & 313.16 & 17. 70 & 1. 1720 & .6458 & .1025 \\
\hline & 30 & 303.16 & 17.41 & 1. 2400 & .6955 & .1024 \\
\hline & 20 & 293. 16 & 17.12 & 1. 3176 & .7525 & .1023 \\
\hline & 10 & 283.16 & 16.83 & 1. 4089 & .8188 & .1022 \\
\hline & 0 & 273.16 & 16.53 & 1. 5084 & .8961 & .1018 \\
\hline & -10 & 263.16 & 16. 22 & 1. 6304 & .9887 & .1017 \\
\hline & -20 & 253.16 & 15.91 & 1. 7725 & 1. 0980 & .1015 \\
\hline & -30 & 243.16 & 15.59 & 1.9455 & 1. 2304 & .1014 \\
\hline & -40 & 233.16 & 15. 27 & 2. 1584 & 1. 3951 & .1013 \\
\hline & -50 & 223.16 & 14.94 & 2. 4304 & 1. 6195 & .1005 \\
\hline \multirow{11}{*}{$45 \ldots$} & +50 & 323.16 & 17.98 & 1. 1535 & 0.6257 & .1025 \\
\hline & 40 & 313.16 & 17.70 & 1. 2111 & .6699 & .1021 \\
\hline & 30 & 303. 16 & 17.41 & 1. 2797 & .7206 & .1020 \\
\hline & 20 & 293. 16 & 17.12 & 1. 3576 & .7787 & .1018 \\
\hline & 10 & 283.16 & 16.83 & 1. 4475 & .8468 & .1016 \\
\hline & 0 & 273.16 & 16.53 & 1. 5505 & .9266 & .1012 \\
\hline & -10 & 263.16 & 16.22 & 1. 6738 & 1. 0207 & .1011 \\
\hline & -20 & 253.16 & 15.91 & 1. 8210 & 1. 1330 & .1010 \\
\hline & -30 & 243.16 & 15.59 & 2. 0104 & 1. 2702 & .1015 \\
\hline & -40 & 233.16 & 15.27 & 2. 2315 & 1. 4396 & .1015 \\
\hline & -50 & 223.16 & 14. 94 & 2. 5148 & 1. 6820 & 1001 \\
\hline \multirow{10}{*}{50} & +50 & 323.16 & 17.98 & 1. 2036 & 0.6643 & .1008 \\
\hline & 40 & 313.16 & 17. 70 & 1. 2639 & .7113 & .1004 \\
\hline & 30 & 303.16 & 17.41 & 1. 3344 & .7640 & .1003 \\
\hline & 20 & 293.16 & 17.12 & 1.4136 & .8248 & .1001 \\
\hline & 10 & 283.16 & 16.83 & 1. 5060 & .8952 & .1000 \\
\hline & 0 & 273.16 & 16.53 & 1. 6117 & .9779 & .0997 \\
\hline & -10 & 263.16 & 16. 22 & 1. 7418 & 1.0766 & .0998 \\
\hline & -20 & 253.16 & 15.91 & 1. 8988 & 1.1952 & .0999 \\
\hline & -30 & 243.16 & 15.59 & 2. 0952 & 1. 3428 & .1001 \\
\hline & -40 & 233.16 & 15. 27 & 2. 3432 & 1. 5284 & .1004 \\
\hline
\end{tabular}
and absolute temperature 
TABLE 9. Relation between resistivity, kinematic viscosity, and absolute temperature-Continued

\begin{tabular}{|c|c|c|c|c|c|c|}
\hline \multirow{2}{*}{$\mathrm{HClO}_{4}$} & & \multicolumn{2}{|c|}{ Temperature } & \multirow{2}{*}{$\begin{array}{l}\log \\
(20 \times \text { kine- } \\
\text { matic vis- } \\
\text { eosity) }\end{array}$} & \multirow{2}{*}{$\begin{array}{l}\log \\
(4 \times \text { resis- } \\
\text { tivity })\end{array}$} & \multirow{2}{*}{$K$} \\
\hline & & $T$ & $\sqrt{T}$ & & & \\
\hline \multirow[t]{5}{*}{ Percent } & ${ }^{\circ} C$ & ${ }^{\circ} A b s$ & $\left({ }^{\circ} A b s\right)^{3 / 2}$ & & & \\
\hline & +50 & 323.16 & 17.98 & 1. 2676 & 0.7203 & 0.0979 \\
\hline & 40 & 313.16 & 17.70 & 1.3308 & .7694 & .0977 \\
\hline & 30 & 303.16 & 17.41 & 1.4018 & .8243 & .0977 \\
\hline & 20 & 293.16 & 17.12 & 1.4843 & .8872 & .0977 \\
\hline \multirow{12}{*}{$55 \ldots \ldots$} & 10 & 283.16 & 16.83 & 1. 5814 & .9611 & .0978 \\
\hline & $\begin{array}{r}0 \\
-10\end{array}$ & 273.16 & 16.53 & 1. 6934 & 1.0480 & .0978 \\
\hline & $\begin{array}{l}-10 \\
-20\end{array}$ & 263.16 & 16. 22 & 1.8322 & 1.1524 & .0980 \\
\hline & $\begin{array}{l}-20 \\
-30\end{array}$ & 253.16 & 15.91 & 2. 0000 & 1. 2792 & .0983 \\
\hline & & 243.16 & 15.59 & 2.1960 & 1.4390 & .0979 \\
\hline & $\begin{array}{l}-40 \\
-50\end{array}$ & 233.16 & 15.27 & 2.4975 & 1. 6478 & .0993 \\
\hline & -50 & 223.16 & 14.94 & 2.9494 & 1. 9562 & .1009 \\
\hline & +50 & 323.16 & 17.98 & 1. 3416 & 0.7896 & .0945 \\
\hline & 40 & 313.16 & 17.70 & 1. 4072 & .8388 & .0948 \\
\hline & 30 & 303.16 & 17.41 & 1.4797 & .8945 & .0950 \\
\hline & 20 & 293.16 & 17.12 & 1.5647 & .9590 & .0953 \\
\hline & 10 & 283.16 & 16.83 & 1.6635 & 1.0342 & .0956 \\
\hline \multirow{11}{*}{$60 \ldots$} & 0 & 273.16 & 16.53 & 1. 7818 & 1.1232 . & .0960 \\
\hline & -10 & 263.16 & 16.22 & 1. 9310 & 1. 2296 & .0968 \\
\hline & -20 & 253.16 & 15.91 & 2.0996 & 1. 3611 & .0970 \\
\hline & -30 & 243.16 & 15.59 & 2. 3084 & 1. 5264 & .0970 \\
\hline & -40 & 233.16 & 15. 27 & 2. 6337 & 1. 7426 & .0990 \\
\hline & -50 & 223.16 & 14.94 & 3.0477 & 2.0350 & .1002 \\
\hline & -60 & 213.16 & 14.60 & 3.6212 & 2.4874 & .0997 \\
\hline & $(+50$ & 323.16 & 17.98 & 1.5092 & 0.9824 & .0854 \\
\hline & 40 & 313.16 & 17.70 & 1. 5754 & 1. 0341 & .0861 \\
\hline & 30 & 303.16 & 17.41 & 1.6488 & 1.0912 & .0868 \\
\hline & 20 & 293.16 & 17.12 & 1. 7314 & 1. 1553 & .0875 \\
\hline \multirow{5}{*}{$70 \ldots \ldots$} & 10 & 282.16 & 16.83 & 1.8283 & 1. 2281 & .0885 \\
\hline & 0 & 273.16 & 16.53 & 1. 9361 & 1. 3121 & .0893 \\
\hline & -10 & 263.16 & 16.22 & 2.0637 & 1.4095 & .0903 \\
\hline & -20 & 253.16 & 15.91 & 2. 2163 & 1. 5261 & .0913 \\
\hline & -30 & 243.16 & 15.59 & 2. 4076 & 1. 6661 & $.0 \Omega 27$ \\
\hline \multirow{2}{*}{\multicolumn{6}{|c|}{$\begin{array}{l}\text { A verage } K \text { (omitting 10-, 20-, and } 70 \text {-percent solutions) } \\
\text { A verage deviation (omitting 10-, 20-, and } 70 \text {-percent solu- } \\
\text { tions) }\end{array}$}} & 0.0995 \\
\hline & & & & & & \pm .0018 \\
\hline \multirow{2}{*}{\multicolumn{6}{|c|}{$\begin{array}{l}\text { A verage } K \text { (all observations) } \\
\text { A verage deviation (all observations) }\end{array}$}} & .0950 \\
\hline & & & & & & \pm .0067 \\
\hline
\end{tabular}

\section{Freezing Temperatures}

The freezing temperatures of the various perchloric-acid solutions used in determining the other physical properties reported in this paper have been measured. On the more complicated parts of the curve, the freezing temperatures of some solutions of intermediate compositions were also measured. No attempt was made, however, to determine the complete phase diagram as had been done earlier by van Wyk [8]. Both van Wyk's data and ours are represented graphically in figure 10.

$$
\text { (a) Measurements }
$$

Freezing and melting temperatures were measured in an apparatus shown in figure 7 . A 25-ml

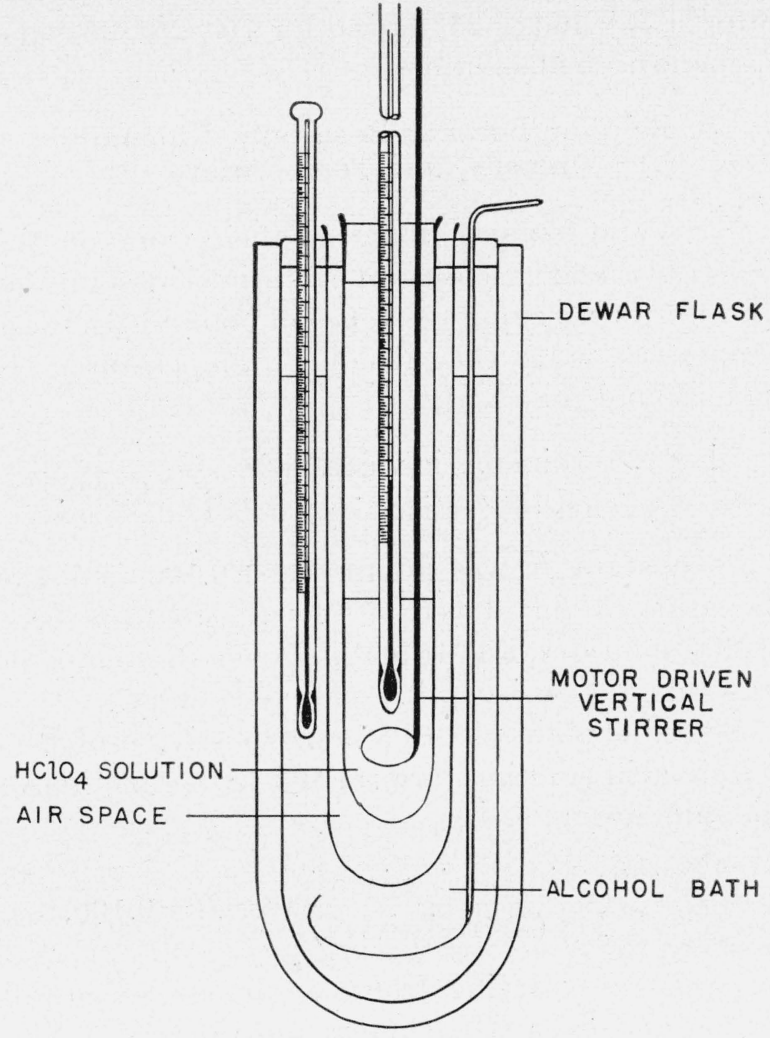

FIGURE 7. Freezing and melting temperature apparatus.

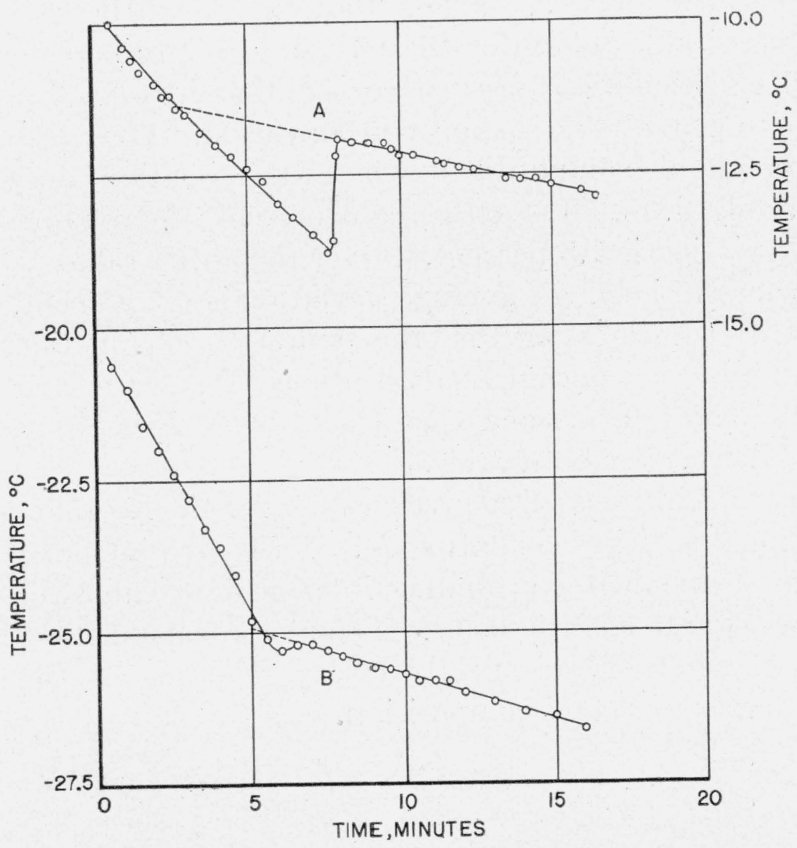

FIGURE 8. Freezing curves for perchloric-acid solutions in region where ice separates as solid phase.

A, 9.7 percent of $\mathrm{HClO}_{4}$; B, 29.2 percent of $\mathrm{HClO}_{4}$. 


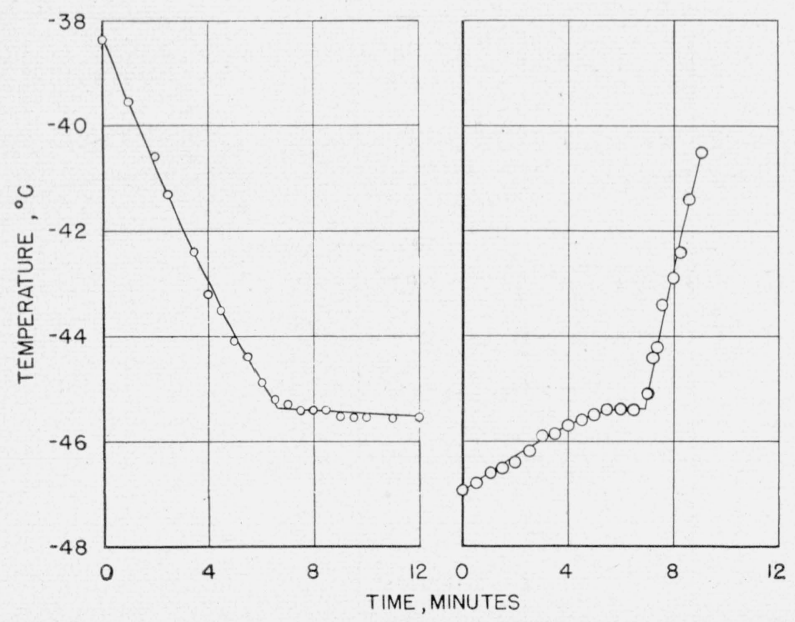

FIgURe 9. Freezing and melting curves for 52-percent $\mathrm{HClO}_{4}$ solution.

sample was insulated from the bath by the air space between two concentric test tubes. A vertical shaft, motordriven stirrer of 100 to 150 strokes per minute was provided for stirring the sample. The alcohol cooling- or warming-bath was contained in a clear Dewar flask. Small amounts of solid carbon dioxide were added to keep the bath some 10 to $20 \mathrm{deg}$ below or above the freezing or melting point of the solution.

The temperature of the solution, which was continually stirred, was read at 30 -sec intervals. These temperatures, plotted with respect to time, gave typical freezing and melting curves. The intersection of the solid and liquid curves gave the freezing or melting points of the solution. Typical curves are shown in figures 8 and 9 . Two or more freezing experiments were made for each solution. Supercooling was especially noticeable in the 60- and 70-percent solutions, where the solution sometimes supercooled as much as $35 \mathrm{deg}$ C. To bring about crystallization close to the freezing temperature, crystals were introduced from a partially frozen auxiliary solution of the same composition. Melting experiments were also run for a number of solutions and the freezing and melting temperatures were found to be in good agreement. These data are given in table 10.

Mercury thermometers with $0.2^{\circ} \mathrm{C}$ divisions were used for solutions up to 30 percent of $\mathrm{HClO}_{4}$.

TABLE 10. Observed freezing and melting points of perchloric-acid solutions

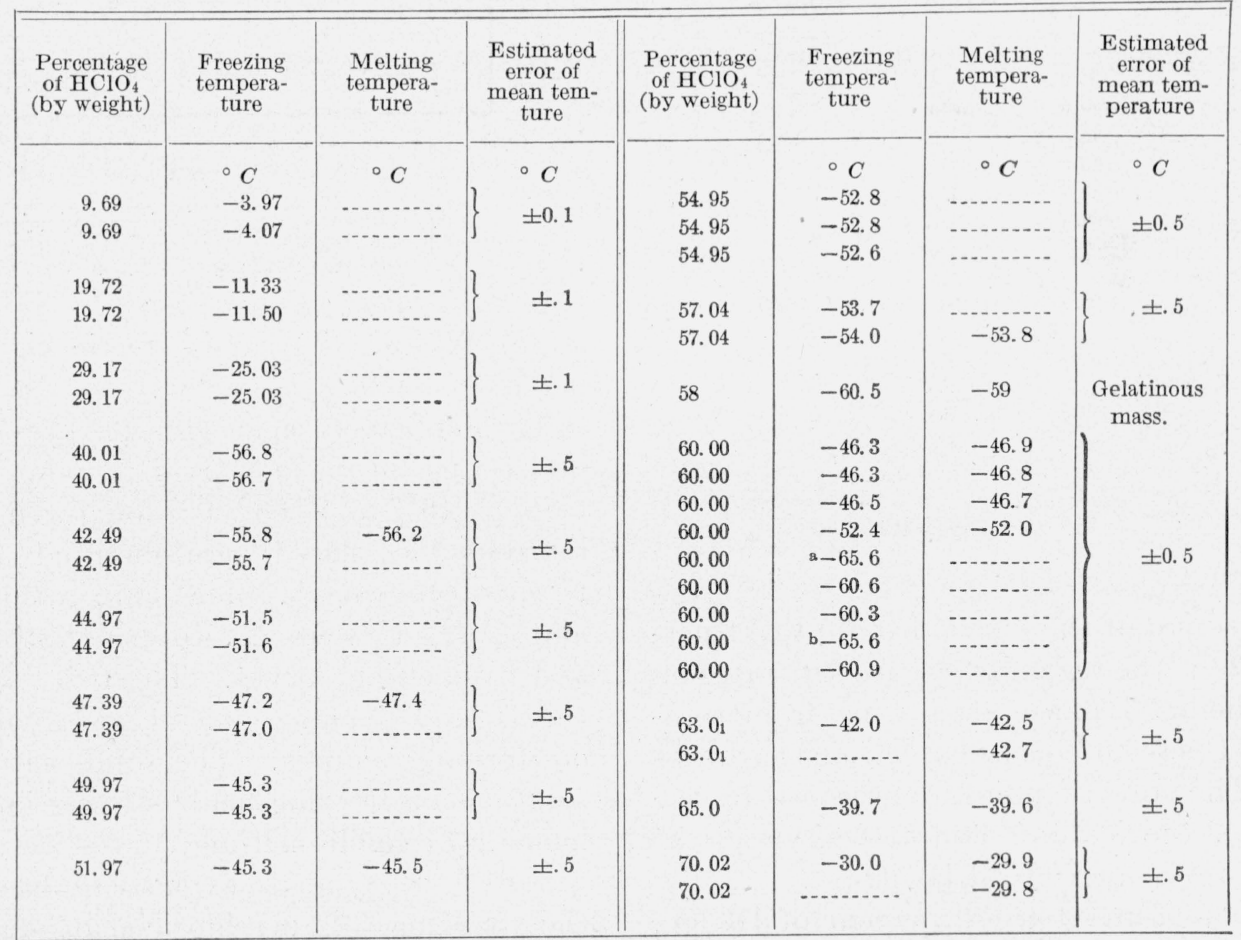

s This and the following two values were observed as flats on the same curve.

b This and the following value were observed as flats on the same curve. 
For the solutions from 40 to 70 percent of $\mathrm{HClO}_{4}$, spirit thermometers with $1^{\circ} \mathrm{C}$ divisions were used. All thermometers had been calibrated, and tabular and emergent-stem corrections were applied for all readings.

\section{(b) Experimental Results}

The experimental freezing and melting temperatures, table 10 , plotted with respect to composition of the perchloric-acid solutions are shown in figure 10, together with van Wyk's more complete data. Freezing temperatures from the NBS curve are given in table 11.

TABLE 11. Freezing temperatures of perchloric-acid solutions (from fig. 10)

\begin{tabular}{|c|c|c|}
\hline $\begin{array}{l}\text { Percentage of } \mathrm{HClO}_{4} \\
\text { (by weight) }\end{array}$ & $\begin{array}{c}\text { Freezing } \\
\text { temperature }\end{array}$ & Solid phase \\
\hline 0 & ${ }^{\circ} \mathrm{C}$ & $\mathrm{H}_{2} \mathrm{O}$ \\
\hline $5 \ldots$ & -1.87 & Do. \\
\hline 10 & -4.25 & Do. \\
\hline $15 \ldots$ & -7.37 & Do. \\
\hline 20 & -11.75 & Do. \\
\hline 25 & -18.2 & Do. \\
\hline $30 \ldots$ & -26.5 & Do. \\
\hline 35 & -39.1 & Do. \\
\hline $40 \ldots$ & -56.8 & Do. \\
\hline $40.7 \ldots$ & -59.7 & $\mathrm{H}_{2} \mathrm{O}, \mathrm{HClO}_{4} x \mathrm{H}_{2} \mathrm{O}$ \\
\hline $42 \ldots$ & -57.0 & $\mathrm{HClO}_{4} x \mathrm{H}_{2} \mathrm{O}$ \\
\hline $44 \ldots$ & -53.2 & Do. \\
\hline $46 \ldots$ & -49.6 & Do. \\
\hline $48 \ldots$ & -46.8 & Do. \\
\hline $50 \ldots$ & -45.0 & Do. \\
\hline $52 \ldots$ & -45.4 & Do. \\
\hline 54 & $\begin{array}{l}-49.1 \\
-56.6\end{array}$ & $\begin{array}{l}\text { Do. } \\
\text { Do. }\end{array}$ \\
\hline $56.1 \ldots$ & -56.8 & $\mathrm{HClO}_{4} . x \mathrm{H}_{2} \mathrm{O}, \mathrm{HClO}_{4} . y \mathrm{H}_{2} \mathrm{O}$ \\
\hline $58 \ldots$ & -51.4 & $\mathrm{HClO}_{4}, y \mathrm{H}_{2} \mathrm{O}$ \\
\hline $60 \ldots$ & -46.7 & Do. \\
\hline $62 \ldots$ & -43.2 & Do. \\
\hline $64 \ldots$ & -40.5 & Do. \\
\hline $66 \ldots$ & {$[-38.4]$} & Do. \\
\hline $70 \ldots$ & -29.9 & $\mathrm{HClO}_{4}, z \mathrm{H}_{2} \mathrm{O}$ \\
\hline
\end{tabular}

The first section of the curve, from 0 to 41 percent of $\mathrm{HClO}_{4}$, is the region where ice separates on freezing. The solid phase separating from solutions above 41 percent consists of various hydrates of $\mathrm{HClO}_{4}$. The eutectic point, determined by the intersection of the ice and hydrate curves, is at $-59.7^{\circ} \mathrm{C}$ and 40.7 percent of $\mathrm{HClO}_{4}$.

In the region from 41 to 70 percent of $\mathrm{HClO}_{4}$, the curve becomes more complicated. Our data lie in general on curves that have the same shape

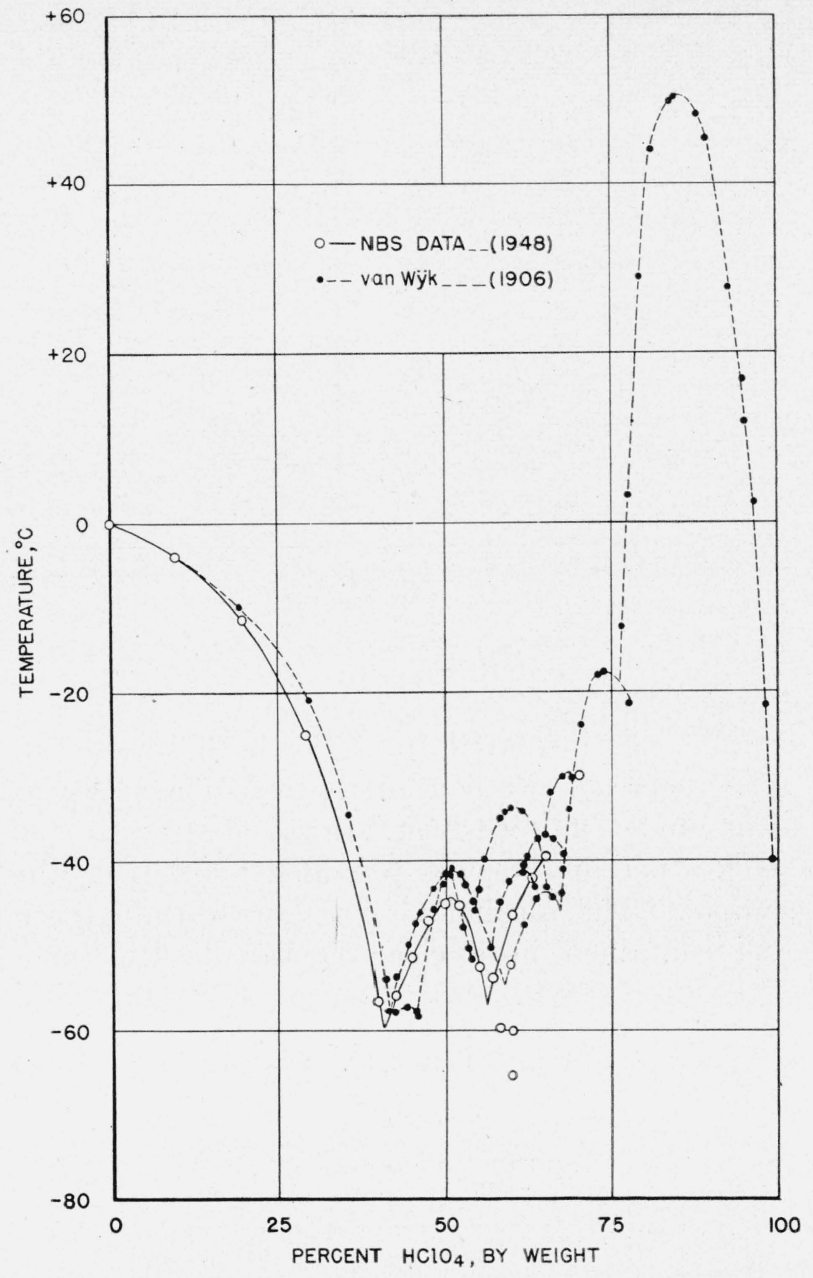

Figure 10. Freezing curves of perchloric acid solutions. ○_ NBS data (1948); - _ - van Wyk's data (1906).

as van Wyk's. A second eutectic was found for 56 percent of acid at $-57^{\circ} \mathrm{C}$.

The 60-percent-acid solution presented a very interesting problem. Over a range of $20 \mathrm{deg}$, from $-46^{\circ}$ to $-66^{\circ} \mathrm{C}$, four well-defined and reproducible "flats" were observed on the timetemperature curves. The temperatures of $-46.5^{\circ}$ and $-52^{\circ} \mathrm{C}$ were determined both by freezing and by melting curves. The two lower temperatures, $-60.5^{\circ}$ and $-65.6^{\circ} \mathrm{C}$, were observed only on freezing curves. The solid nature of these solutions on freezing made stirring impossible and hence no reliable melting curves were obtainable.

van Wyk [8] made extensive measurements on the freezing of perchloric-acid solutions. His data, converted to weight percent, have been plotted in figure 10. The temperatures observed 
by van Wyk are in many cases outside the experimental error of the NBS work. Since van Wyk gave no diagram of his freezing apparatus, used no stirrer except his thermometer, did not in general plot time-temperature curves, and gave no indication of having made corrections for emergent-stem temperatures for his alcohol thermometer, it is not possible to estimate the accuracy of his temperatures.

\section{Properties of Perchloric-Acid Solutions Applied to Batteries}

With the recent demands for more powerful batteries to operate at extreme low temperatures, the NBS perchloric-acid battery [9] was developed. The physical properties of the acid solutions reported in section I were measured to supplement meager data in the literature. Some comparisons of solutions of sulfuric and perchloric acids used in batteries are given here. Since during discharge of the lead-acid battery various concentrations of lead ions are in solution, resistivities of perchloricacid solutions containing lead have been measured.

\section{Comparison of Sulfuric- and Perchloric-Acid Solutions}

(a) Viscosities

A comparison of perchloric and sulfuric acids ordinarily used in batteries is of interest. A 50percent solution of perchloric acid is one that has been used in batteries designed for service over wide ranges of temperature, and 37 percent of sulfuric acid (sp gr 1.280) is the usual solution in the fully charged lead-acid storage battery. In table 12 the viscosities of these solutions are compared from $+30^{\circ}$ to $-40^{\circ} \mathrm{C}$. The perchloric acid is, in all cases, less viscous than the sulfuric. At room temperatures the viscosity of the perchloric is only three-fourths that of the sulfuric and at the lower temperatures it is only six-tenths as much.

In table 13 the viscosities of perchloric and sulfuric acids of the same equivalent strengths are compared. Acids containing 50 percent of $\mathrm{HClO}_{4}$ and 28.41 percent of $\mathrm{H}_{2} \mathrm{SO}_{4}$ each contains 6.964 gram-equivalents per liter. At room temperature perchloric acid is slightly less viscous than the equivalent sulfuric acid, but at the lower temperatures it is only 80 percent as viscous.
TABLE 12. Comparison of viscosities of perchloric- and sulfuric-acid solutions of concentrations commonly used in the respective types of batteries

\begin{tabular}{|c|c|c|c|}
\hline Temperature & $50 \% \mathrm{HClO}_{4}$ & $\begin{array}{c}\text { Sulfuric acid, } \\
1.280 \mathrm{sp} \mathrm{gra}^{\mathrm{a}} \\
\left(37.4 \% \mathrm{H}_{2} \mathrm{SO}_{4}\right)\end{array}$ & $\begin{array}{c}\text { Ratio } \\
\eta_{\mathrm{HClO}_{4} / \eta_{\mathrm{H}_{2} \mathrm{SO}_{4}}}\end{array}$ \\
\hline $\begin{array}{r}{ }^{\circ} \mathrm{C} \\
+50\end{array}$ & $\begin{array}{c}\text { Centipoises } \\
1.10\end{array}$ & Centipoises & \\
\hline+40 & 1. 27 & $\begin{array}{l}-1 \\
-1\end{array}$ & - \\
\hline$+30 \ldots$ & 1. 51 & 1. 94 & 0.78 \\
\hline+25 & 1.65 & 2. 22 & .74 \\
\hline$+20 \ldots$ & 1. 82 & 2. 49 & .73 \\
\hline$+10 \ldots$ & 2. 27 & 3. 22 & .70 \\
\hline 0 & 2. 91 & 4.35 & .67 \\
\hline$-10 \ldots$ & 3. 96 & 6.15 & .64 \\
\hline$-20 \ldots$ & 5. 73 & 9.15 & .63 \\
\hline$-30 \ldots$ & 9. 08 & 14.9 & .61 \\
\hline$-40 \ldots$ & 16.2 & 26.9 & .60 \\
\hline$-50 \ldots$ & - & 55.5 & 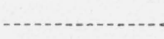 \\
\hline
\end{tabular}

a G. W. Vinal and D. N. Craig, BS J. Research 10, 781 (1933) RP566.

TABLE 13. Comparison of perchloric- and sulfuric-acid solutions containing the same number of equivalents of the respective acids per liter

\begin{tabular}{|c|c|c|c|}
\hline Temperature & $\begin{array}{l}50 \% \text { HClO } \\
\text { (6.964 gram- } \\
\text { equivalents/ } \\
\text { liter) }\end{array}$ & $\begin{array}{c}28.41 \% \mathrm{H}_{2} \mathrm{SO}_{4}{ }^{\mathrm{a}} \\
\text { (6.964 gram- } \\
\text { equivalents/ } \\
\text { liter) }\end{array}$ & $\begin{array}{c}\text { Ratio } \\
\eta_{\mathrm{HClO}_{4}} / \eta_{\mathrm{H}_{2} \mathrm{SO}_{4}}\end{array}$ \\
\hline${ }^{\circ} \mathrm{C}$ & Centipoises & Centipoises & \\
\hline $\begin{array}{l}+50 \ldots \\
+40 \ldots\end{array}$ & $\begin{array}{l}1.10 \\
1.27\end{array}$ & - & -- \\
\hline+30 & 1.51 & 1. 54 & 0.98 \\
\hline$+25 \ldots$. & 1.65 & 1.71 & .96 \\
\hline$+20 \ldots$ & 1.82 & 1.93 & .94 \\
\hline$+10 \ldots$ & 2. 27 & 2. 49 & .91 \\
\hline $0 \ldots \ldots$ & 2. 91 & 3.37 & .86 \\
\hline-10 & 3.96 & 4.78 & .83 \\
\hline$-20 \ldots$ & 5.73 & 7. 22 & .79 \\
\hline$-30 \ldots$ & 9.08 & 11.7 & .78 \\
\hline$-40 \ldots$ & 16.2 & & -. \\
\hline
\end{tabular}

a G. W. Vinal and D. N. Craig, BS J. Research 10, 781 (1933) RP566.

(b) Resistivities

For each temperature the concentration of $\mathrm{HClO}_{4}$ having minimum resistivity is 36 percent (fig. 6 and table 14). Forty percent of acid, which is the lowest concentration commonly used in experimental batteries, has a resistivity only about 2 percent higher than the minimum resistivity at each temperature. As the concentration of acid is increased, the resistivity increases markedly. Ratios of the resistivities of 45 - to 70 -percent acid to the resistivity of 40 percent acid are given for various temperatures in table 15 . 
TABLE 14. Comparison of minimum resistivities of perchloric- and sulfuric-acid solutions for the various temperatures a

\begin{tabular}{|c|c|c|c|c|c|}
\hline \multirow{2}{*}{ Temperature } & \multicolumn{2}{|c|}{ Perchloric acid } & \multicolumn{2}{|c|}{ Sulfuric acid } & \multirow{2}{*}{$\begin{array}{l}\text { Ratio of } \\
\text { col. } 3 \text { to } \\
\text { col. } 5\end{array}$} \\
\hline & $\begin{array}{l}\text { Concen- } \\
\text { tration }\end{array}$ & $\begin{array}{l}\text { Resis- } \\
\text { tivity }\end{array}$ & $\begin{array}{l}\text { Concen- } \\
\text { tration }\end{array}$ & $\begin{array}{l}\text { Resis- } \\
\text { tivity }\end{array}$ & \\
\hline${ }^{\circ} \mathrm{C}$ & Percent & $\mathrm{Ohm}-\mathrm{cm}$ & Percent & $\mathrm{Ohm}-\mathrm{cm}$ & \\
\hline$+50 \ldots$ & 36 & 0.988 & .... & ..... & $\ldots$ \\
\hline$+40 \ldots$ & 36 & 1.093 & $\ldots$ & ..... & -...- \\
\hline$+30 \ldots$ & 36 & 1. 221 & 31.5 & 1. 129 & 1.08 \\
\hline$+25 \ldots$ & 36 & 1. 300 & 31.1 & 1. 213 & 1. 07 \\
\hline$+20 \ldots$ & 36 & 1. 392 & 30.6 & 1. 310 & 1.06 \\
\hline$+15 \ldots$ & 36 & 1. 499 & 30.2 & 1.425 & 1.05 \\
\hline$+10 \ldots$ & 36 & 1. 617 & 29.8 & 1. 562 & 1.03 \\
\hline 0 & 36 & 1. 920 & 28.8 & 1. 928 & 1.00 \\
\hline$-10 \ldots$ & 36 & 2. 38 & 27.9 & 2.48 & 0.96 \\
\hline$-20 \ldots$ & 36 & 3.08 & 26.9 & 3.34 & .92 \\
\hline$-30 \ldots$ & 36 & b (4.23) & $-\cdots$ & ..... & -... \\
\hline-40 & 36 & $\mathrm{~b}(6.14)$ & --- & $\ldots-\cdots$ & -... \\
\hline
\end{tabular}

3 Isotherms for the resistivity of perchloric acid are shown in figure 6. For sulfuric acid, reference should be made to figure 1 of the paper by Vinal and Craig [7]

b Extrapolated value.

TABLE 15. Ratio of resistivities to resistivity of 40-percent$\mathrm{HClO}_{4}$ solutions

\begin{tabular}{|c|c|c|c|c|c|c|}
\hline \multirow{2}{*}{$\begin{array}{l}\text { Temper- } \\
\text { ature }\end{array}$} & \multicolumn{6}{|c|}{ Percentage of $\mathrm{HClO}_{4}-$} \\
\hline & 45 & 50 & 55 & 60 & 65 & 70 \\
\hline${ }^{\circ} C$ & & & & & & \\
\hline$+50 \ldots$ & 1.055 & 1.153 & 1.312 & 1.538 & 1. 901 & 2. 399 \\
\hline$+40 \ldots \ldots$ & 1. 057 & 1. 163 & 1.329 & 1.560 & 1. 920 & 2. 445 \\
\hline$+30 \ldots \ldots$ & 1. 060 & 1.171 & 1.345 & 1.581 & 1. 949 & 2.487 \\
\hline$+25 \ldots \ldots \ldots$ & 1.064 & 1.175 & 1.358 & 1.596 & 1.968 & 2. 511 \\
\hline$+20 \ldots \ldots$ & 1.062 & 1.181 & 1. 364 & 1.609 & 1.963 & 2.528 \\
\hline$+15 \ldots \ldots$ & 1. 066 & 1. 186 & 1. 378 & 1.627 & 1.993 & 2. 541 \\
\hline$+10 \ldots \ldots$ & 1. 067 & 1. 192 & 1. 388 & 1.642 & 2. 048 & 2.567 \\
\hline $0 \ldots \ldots$ & 1. 072 & 1. 207 & 1. 419 & 1. 687 & 2.093 & 2. 606 \\
\hline$-10 \ldots \ldots$ & 1. 076 & 1.224 & 1.458 & 1. 741 & 2. 151 & 2. 635 \\
\hline$-20 \ldots$ & 1. 084 & 1. 251 & 1.518 & 1. 832 & 2. 225 & 2. 678 \\
\hline$-30 \ldots \ldots$ & 1. 096 & 1. 297 & 1. 617 & 1.977 & 2. 348 & 2. 727 \\
\hline$-40 \ldots$ & 1.11 & 1. 36 & 1. 79 & 2. 22 & -...- & -... \\
\hline$-50 \ldots$ & 1.16 & $\ldots$ & 2.17 & 2. 60 & ..... & ..... \\
\hline
\end{tabular}

The choice of concentrations of perchloric acid for use in any particular application of a battery depends on a variety of conditions, such as the current drain, the lowest temperatures to which the batteries may be exposed, the materials employed in construction, and the permissible volume of the electrolyte. No acid stronger than 70 percent is used, and the lower limit is probably 40 percent. The tables therefore cover the entire range of concentrations and temperatures that may be needed for any application of the battery.

The minimum resistivities for perchloric- and sulfuric-acid solutions are given in table 14 . Over the whole temperature range, from $+50^{\circ}$ to $-40^{\circ} \mathrm{C}$, the perchloric acid of minimum resistivity is very close to 36 percent by weight. The composition of sulfuric acid, on the other hand, shifts from 31.5 percent at $+30^{\circ} \mathrm{C}$ to 26.9 percent at $-20^{\circ} \mathrm{C}$ for minima in the resistivity curves. For temperatures above $0^{\circ} \mathrm{C}$, sulfuric acid has lower minimum resistivities than perchloric acid, whereas for temperatures below $0^{\circ}$ $\mathrm{C}$, the sulfuric acid minima are higher than those of perchloric acid.

A comparison of the resistivities of perchloricand sulfuric-acid solutions of concentrations commonly used in the respective types of batteries is given in table 16. Fifty percent of perchloric acid is compared with sulfuric acid of $1.280 \mathrm{sp}$ gr $25^{\circ} \mathrm{C} / 25^{\circ} \mathrm{C}\left(37.4 \%\right.$ of $\mathrm{H}_{2} \mathrm{SO}_{4}$ by weight). For temperatures above $-30^{\circ} \mathrm{C}$, the resistivity of the sulfuric acid is less than that of the perchloric acid. At $-40^{\circ} \mathrm{C}$, however, the resistivity of perchloric acid is 3 percent less than that of the sulfuric.

TABLE 16. Comparison of resistivities of perchloric- and sulfuric-acid solutions of concentrations commonly used in the respective types of batteries

\begin{tabular}{|c|c|c|c|}
\hline Temperature & $\begin{array}{c}\text { Perchloric } \\
\text { acid, } 50 \\
\text { percent }\end{array}$ & $\begin{array}{l}\text { Sulfuric acid, } \\
1.280 \mathrm{sp} \text { gr } \\
37.4 \text { percent }\end{array}$ & $\begin{array}{l}\text { Ratio, col. } 2 \\
\text { to col. } 3\end{array}$ \\
\hline${ }^{\circ} C$ & Ohm-cm & $\mathrm{Ohm}-\mathrm{cm}$ & \\
\hline$+50 \ldots \ldots$ & 1. 154 & - n. & - \\
\hline$+40 \ldots$ & 1. 286 & .......... & - n \\
\hline+30 & 1. 452 & 1.165 & 1. 25 \\
\hline$+25 \ldots$ & 1. 551 & 1. 258 & 1. 23 \\
\hline+20 & 1. 670 & 1. 367 & 1. 22 \\
\hline+15 & 1. 809 & 1.493 & 1.21 \\
\hline$+10 \ldots \ldots$ & 1. 964 & 1. 649 & 1.19 \\
\hline 0 & 2. 376 & 2.064 & 1.15 \\
\hline$-10 \ldots \ldots$ & 2. 98 & 2. 69 & 1.11 \\
\hline-20 & 3.92 & 3. 68 & 1.06 \\
\hline$-30 \ldots$ & 5. 51 & 5.41 & 1.02 \\
\hline-40 & 8.44 & 8. 71 & 0.97 \\
\hline
\end{tabular}

A further comparison between perchloric- and sulfuric-acid solutions can be made for acids that have the same number of equivalents per liter. Fifty percent of $\mathrm{HClO}_{4}$ is equivalent to 28.41 percent of $\mathrm{H}_{2} \mathrm{SO}_{4}$; each solution contains 6.964 gram-equivalents per liter. The resitivities of 
these acids are given in table 17 . For each temperature the resistivity of perchloric is greater than that of sulfuric acid, but as the temperature is lowered the ratio of the resistivity of perchloric to the resistivity of sulfuric decreases.

TABLE 17. Comparison of resistivities of perchloric- and sulfuric-acid solutions containing the same number of equivalents of the respective acids per liter

\begin{tabular}{|c|c|c|c|}
\hline Temperature & $\begin{array}{l}50 \text { percent } \\
\mathrm{HClO} \text {, } 6.964 \\
\text { gram-equiv- } \\
\text { alents/liter }\end{array}$ & $\begin{array}{c}28.41 \text { percent } \\
\mathrm{H}_{2} \mathrm{SO}_{4}, 6.964 \\
\text { gramequiv- } \\
\text { alents/liter }\end{array}$ & $\begin{array}{l}\text { Ratio of col } \\
2 \text { to col } 3\end{array}$ \\
\hline${ }^{\circ} \mathrm{C}$ & Ohm-cm & $\mathrm{Ohm}-\mathrm{cm}$ & \\
\hline+50 & 1. 154 & -......... & $\cdots$ \\
\hline+40 & 1. 286 & - & …… \\
\hline+30 & 1. 452 & 1. 139 & 1. 274 \\
\hline+25 & 1. 551 & 1. 221 & 1. 270 \\
\hline+20 & 1. 670 & 1.317 & 1. 268 \\
\hline+15 & 1. 809 & 1. 431 & 1. 264 \\
\hline+10 & 1. 964 & 1. 566 & 1. 254 \\
\hline 0 & 2. 376 & 1. 928 & 1. 232 \\
\hline-10 & 2. 98 & 2.48 & 1. 20 \\
\hline-20 & 3. 92 & 3.36 & 1.17 \\
\hline-30 & 5. 51 & 4.95 & 1.11 \\
\hline-40 & 8.44 & -....... & .......... \\
\hline
\end{tabular}

Perchloric, like sulfuric, is a strong acid which provides solutions of low resistivity (high conductivity). On a practical basis, the comparison of solutions that would normally be employed in batteries shows an advantage for the perchloric acid solutions at the lower temperatures. The data given in these tables and graphically represented in figure 6 should enable one to select the best perchloric-acid electrolyte for any specified condition of operation.

\section{Resistivity of Perchloric-Acid Solutions Containing Lead Perchlorate}

\section{(a) Apparatus}

The apparatus and bridge used in making these measurements were the same as those used for the resistivities of perchloric-acid solutions described in section I, 4.

Solutions equivalent to the solution in a battery after different stages of discharge were prepared by adding basic lead carbonate $\left(\mathrm{PbCO}_{3}\right)_{2} \cdot \mathrm{Pb}(\mathrm{OH})_{2}$ (assay $78.62 \% \mathrm{~Pb}$ ) to various perchloric-acid solutions in amounts required to yield solutions containing $0,5.0,10.0,20.0$, and 30.0 percent of $\mathrm{Pb}$. The initial solutions contained $30.1,40.2,50.0$, 60.0 , and 69.9 percent of $\mathrm{HClO}_{4}$. The composition of the initial acids was determined by measuring the resistivity, and several solutions were checked by density determinations. The $\mathrm{Pb}$ content and the $\mathrm{HClO}_{4}$ content of the various solutions after the addition of the salt $\left(\mathrm{PbCO}_{3}\right)_{2} \cdot \mathrm{Pb}(\mathrm{OH})_{2}$ were calculated from the carefully weighed portions of this salt that were added to weighed portions of acid solutions. The free acid remaining in six of the solutions was determined by weight titrations. Since the calculated values did not differ by more than 0.2 percent from the titrated values, the calculated acid compositions of all the solutions were considered satisfactory.

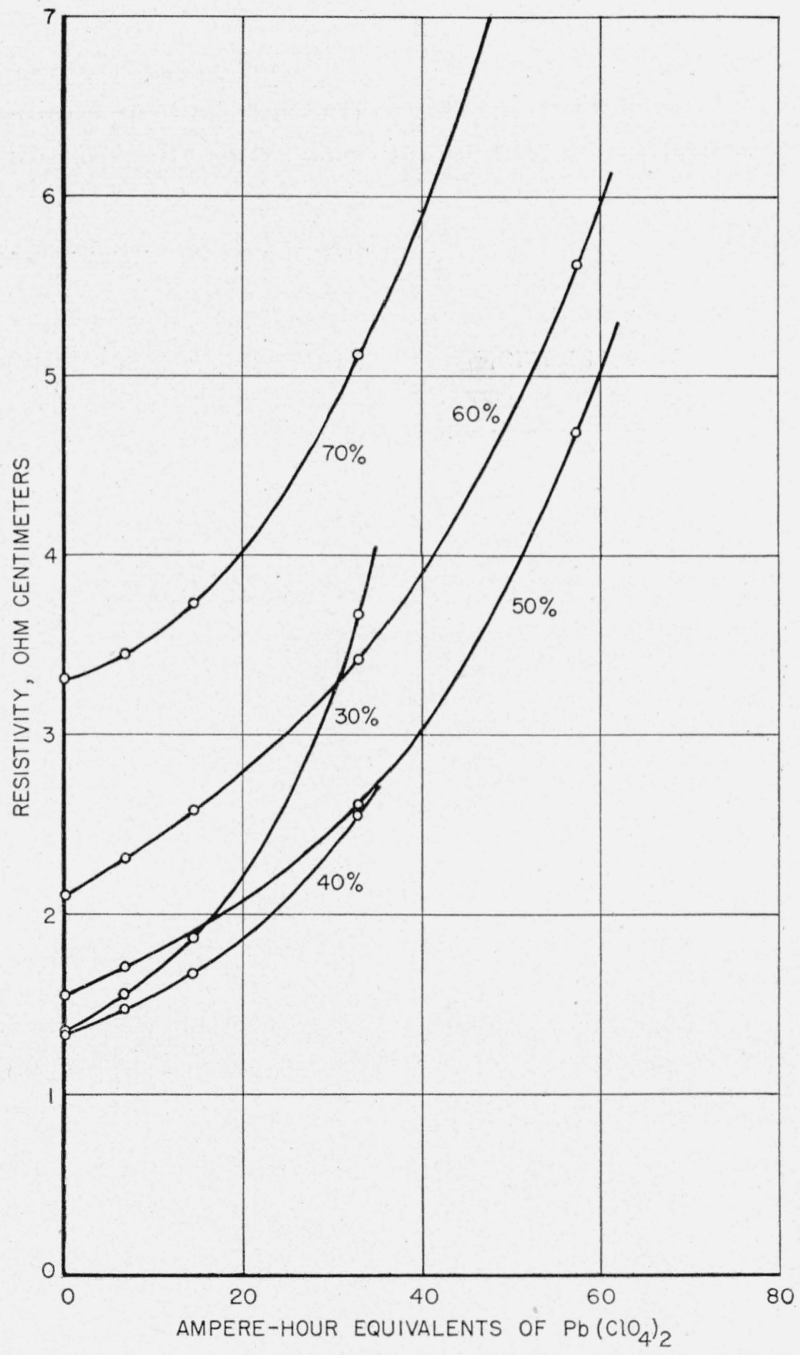

FIgURe 11. Resistivities at $25^{\circ} \mathrm{C}$ of solutions containing initially $1,000 \mathrm{~g}$ of the specified concentrations of $\mathrm{HClO}_{4}$, in which the indicated amounts of lead perchlorate have been formed.

1 ampere hour= $=15.14 \mathrm{~g}$ of $\mathrm{Pb}\left(\mathrm{ClO}_{4}\right)_{2}$. 
(b) Experimental Measurements

The resistance of each solution was measured at $+50^{\circ},+25^{\circ}, 0^{\circ}$, and $-25^{\circ}$, and at $-40^{\circ} \mathrm{C}$ if the solution did not freeze at that temperature. Some solutions were also measured at $+75^{\circ} \mathrm{C}$. Several measurements were made at each temperature and the mean value used in calculating the resistivity. Plots relating resistivity to temperature were used for interpolating the resistivities at even temperature values. For each temperature and for each lead content a curve relating resistivity to the percentage of $\mathrm{HClO}_{4}$ was drawn. From these largescale work-curves, values used in plotting the curves of figure 11 and similar curves for $-40^{\circ}$, $-25^{\circ}, 0^{\circ},+50^{\circ}$, and $+75^{\circ} \mathrm{C}$ were read.

The reaction in the NBS battery containing perchloric acid may be represented by the equation

$$
\mathrm{Pb}+\mathrm{PbO}_{2}+4 \mathrm{HClO}_{4}=2 \mathrm{~Pb}\left(\mathrm{ClO}_{4}\right)_{2}+2 \mathrm{H}_{2} \mathrm{O} .
$$

By this reaction, $15.14 \mathrm{~g}$ of $\mathrm{Pb}\left(\mathrm{ClO}_{4}\right)_{2}$ is formed for each ampere-hour the battery is discharged. For cells containing initially $1,000 \mathrm{~g}$ of perchloric-acid solution, the number of ampere-hours and the final $\mathrm{HClO}_{4}$ content were calculated for solutions containing 5, 10, 20, and 30 percent of $\mathrm{Pb}$. The solutions calculated for the perchloric-acid battery after various discharges had the same $\mathrm{Pb}$ content but slightly different $\mathrm{HClO}_{4}$ content from the experimental solutions formed by adding basic lead carbonate to the perchloric-acid solutions. The resistivity corresponding to the exact acid content of the battery solutions was read from the large-scale work-curves, described above, which related resistivity to percentage of $\mathrm{HClO}_{4}$.

The curves of figure 11 relate the resistivity at

TABLE 18. Resistivities of $\mathrm{HClO}_{4}-\mathrm{Pb}\left(\mathrm{ClO}_{4}\right)_{2}-\mathrm{H}_{2} \mathrm{O}$ solutions

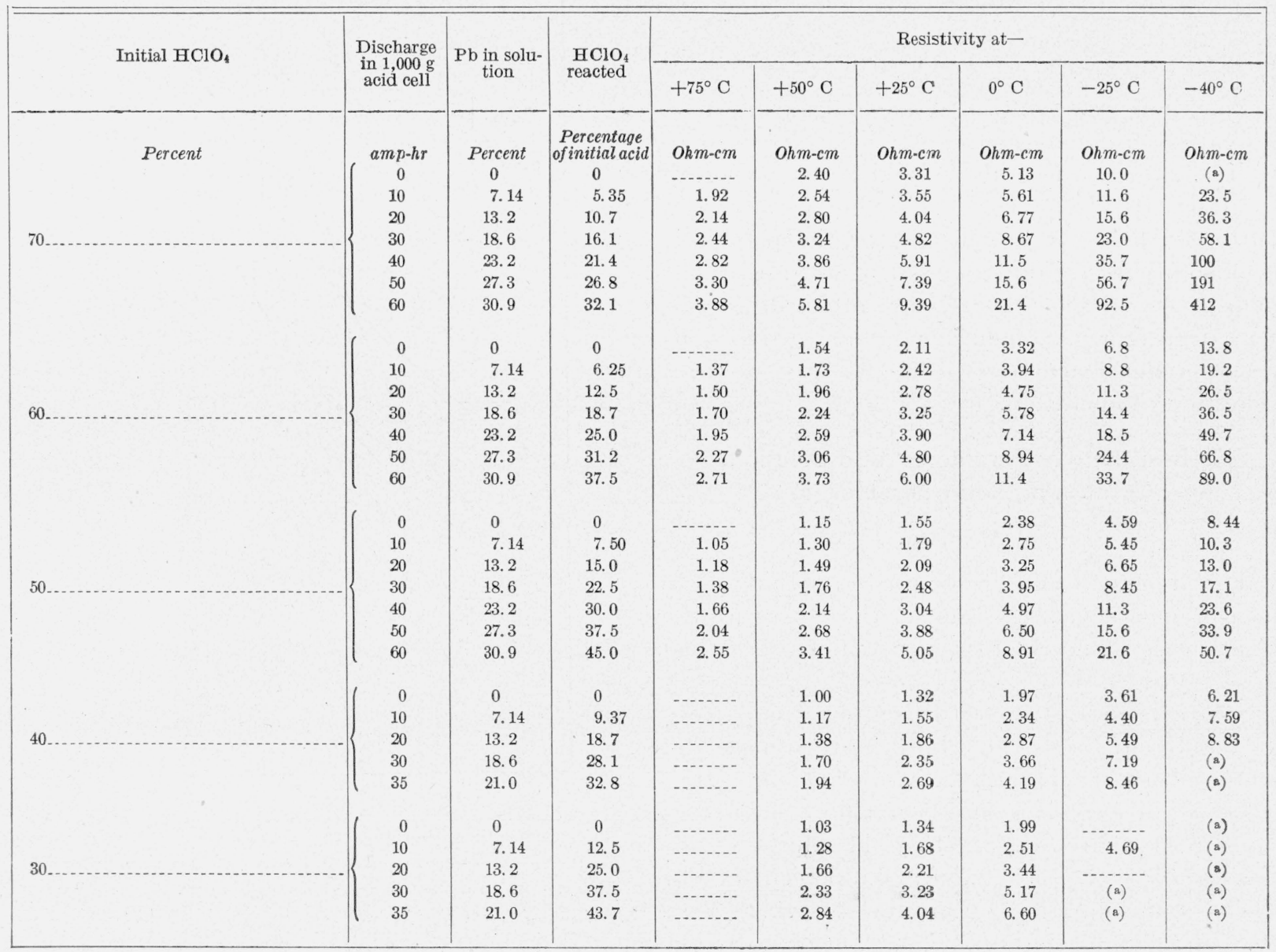

solution freezes. 
$+25^{\circ} \mathrm{C}$ of solutions, equivalent to those in a battery, to the ampere-hour discharge. The various curves represent the conditions in a battery that initially contained $1,000 \mathrm{~g}$ of $30-, 40-, 50-, 60-$; or 70-percent $\mathrm{HClO}_{4}$ solutions by weight. As the battery discharges, i. e., as $\mathrm{H}^{+}$ions are replaced by $\mathrm{Pb}^{++}$ions, the resistivity of the solutions increases. The effect of temperature on resistivity is increasingly important as the battery discharges.

For every 5 ampere-hours, the resistivity values were read from each curve of figure 11 and similar curves for each experimental temperature. The differences between successive values were plotted and smoothed. These smoothed values are given for 10-ampere-hour intervals in table 18.

\section{(c) Accuracy of Measurements}

Errors introduced in the measurements from $-40^{\circ}$ to $+25^{\circ} \mathrm{C}$ by uncertainties in the value of the cell constant, the heating effect of the current through the cell, and the measurement of resistance were less than 0.05 percent, as shown for the resistivity of perchloric-acid solutions (section I, 4). These uncertainties were the same for measurements at $+50^{\circ}$ and $+75^{\circ} \mathrm{C}$ except for the cell constant, where the uncertainty was less than 0.5 percent and usually about 0.2 percent.

Uncertainties from other sources in the resistivity measurements of solutions containing $\mathrm{Pb}^{++}$ ions are somewhat larger than for solutions of the pure acid. The composition of the solutions was known to about 0.2 percent, and the corresponding uncertainty in resistivity was 0.2 percent. Temperatures were controlled and measured to about 0.05 to $0.1 \mathrm{deg} \mathrm{C}$ above $-30^{\circ} \mathrm{C}$, and to about $0.3 \mathrm{deg}$ at $-40^{\circ} \mathrm{C}$. These uncertainties in the temperatures of the solution did not introduce uncertainties greater than 0.4 percent above $-30^{\circ} \mathrm{C}$

TABLE 19. Relative resistivities

\begin{tabular}{|c|c|c|c|c|c|c|c|c|}
\hline \multicolumn{2}{|c|}{$\begin{array}{l}\text { Discharge }{ }^{a}{ }_{-}(a m p-h r) \\
\text { Percent } \mathrm{Pb}\end{array}$} & $\begin{array}{r}0 \\
0\end{array}$ & $\begin{array}{r}10 \\
7.14\end{array}$ & $\begin{array}{c}20 \\
13.2\end{array}$ & $\begin{array}{c}30 \\
18.6\end{array}$ & $\begin{array}{c}40 \\
23.2\end{array}$ & $\begin{array}{c}50 \\
27.3\end{array}$ & $\begin{array}{c}60 \\
30.9\end{array}$ \\
\hline $\begin{array}{l}\text { Tempera- } \\
\text { ture }\end{array}$ & $\begin{array}{l}\text { Initial } \\
\mathrm{HClO}_{4} \\
\text { content }\end{array}$ & \multicolumn{7}{|c|}{ Ratio of resistivities to resistivity of 70 -percent solutions } \\
\hline \multirow[t]{2}{*}{${ }^{\circ} \mathrm{C}$} & Percent & & & & & & & \\
\hline & 70 & - & 1.00 & 1.00 & 1.00 & 1.00 & 1.00 & 1.00 \\
\hline \multirow{3}{*}{-40} & 60 & 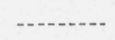 & 0.817 & 0.730 & 0.626 & 0.496 & 0.350 & 0.216 \\
\hline & 50 & - & .438 & .358 & .294 & .236 & .177 & .123 \\
\hline & 40 & - n & .323 & .243 & - n & - n & - n-n & $-1-10-10$ \\
\hline \multirow{4}{*}{-25} & 70 & 1.00 & 1.00 & 1.00 & 1.00 & 1.00 & 1.00 & 1.00 \\
\hline & 60 & 0.679 & 0.754 & 0.724 & 0.626 & 0.518 & 0.430 & 0.364 \\
\hline & 50 & .459 & .470 & .426 & .367 & .318 & .274 & .233 \\
\hline & 40 & .361 & .379 & .352 & .313 & - & - & . \\
\hline \multirow{5}{*}{0} & 70 & 1.00 & 1.00 & 1.00 & 1.00 & 1.00 & 1.00 & 1.00 \\
\hline & 60 & 0.647 & 0.702 & 0.701 & 0.666 & 0.620 & 0.573 & 0.533 \\
\hline & 50 & .463 & .490 & .480 & .455 & .432 & .417 & .417 \\
\hline & 40 & .384 & .417 & .424 & .422 & $(.419)$ & - & - \\
\hline & 30 & .388 & .447 & .508 & .596 & - & - n & - n \\
\hline \multirow{5}{*}{+25} & 70 & 1.00 & 1.00 & 1.00 & 1.00 & 1.00 & 1.00 & 1.00 \\
\hline & 60 & 0.635 & 0.682 & 0.688 & 0.674 & 0.660 & 0.649 & 0.639 \\
\hline & 50 & .468 & .504 & .517 & .515 & .514 & .525 & .538 \\
\hline & 40 & .398 & .437 & .460 & .488 & - & - & - \\
\hline & 30 & .406 & .473 & .547 & .670 & - & - & - \\
\hline \multirow{5}{*}{+50} & 70 & 1.00 & 1.00 & 1.00 & 1.00 & 1.00 & 1.00 & 1.00 \\
\hline & 60 & 0.642 & 0.682 & 0.700 & 0.692 & 0.670 & 0.650 & 0.642 \\
\hline & 50 & .481 & .513 & .532 & .543 & .554 & .569 & .587 \\
\hline & 40 & .417 & .460 & .491 & .523 & - & -....... & - \\
\hline & 30 & .428 & .505 & .593 & .719 & - & . & . \\
\hline \multirow{3}{*}{+75} & 70 & 1.00 & 1.00 & 1.00 & 1.00 & 1.00 & 1.00 & 1.00 \\
\hline & 60 & - & 0.714 & 0.701 & 0.697 & 0.693 & 0.688 & 0.698 \\
\hline & 50 & - & .547 & .551 & .566 & .590 & .618 & .656 \\
\hline
\end{tabular}

a Discharge for cell that initially contained 1,000 $\mathrm{g}$ of perchloric-acid solution. 
and 2.5 percent at $-40^{\circ} \mathrm{C}$. To summarize, the uncertainty of values in the vicinity of the experimental points is probably less than 1 percent above $-30^{\circ} \mathrm{C}$ and 3 percent at $-40^{\circ} \mathrm{C}$.

Values intermediate between the experimentally determined values may be in error by several percent. The largest uncertainties are in the resistivities at $-40^{\circ} \mathrm{C}$ for the more concentrated $\mathrm{Pb}\left(\mathrm{ClO}_{4}\right)_{2}-\mathrm{HClO}_{4}$ solutions-solutions corresponding to those in batteries after 35 to 60 ampere-hour discharges. Here the uncertainty may be as much as 5 percent. For all other measurements the uncertainties probably do not exceed 3 percent and in most cases are less than 2 percent.

\section{(d) Discussion of Results}

A comparison of the relative resistivities of solutions during discharges of batteries which initially contained acids of different $\mathrm{HClO}_{4}$ content is interesting. The ratios of the resistivity of the various solutions to the resistivity of a "70-percent-acid battery" 3 are given in table 19 for various discharges over the temperature range from $-40^{\circ}$ to $+75^{\circ} \mathrm{C}$.

From table 19 it can be seen that at room and higher temperatures the relative resistivities change very little as the battery discharges. Throughout the discharge at room temperature the resistivity of the 60-percent-acid battery is about two-thirds that of the 70-percent-acid battery solution, the 50-percent battery about onehalf, and the 40-percent battery slightly less than one-half. The ratio of the 30-percent to the 70percent battery solution does increase somewhat with the discharge.

The number of ampere-hours that a battery containing initially 1,000 grams of perchloric-acid solution may be discharged before the acid content has decreased to 10 percent is given in table 20. This is an indication of the low-rate-discharge capacity of batteries containing a given weight of solution of different perchloric-acid concentrations.

\footnotetext{
3 The phrase "70-percent-acid battery" is used to refer to a solution in which the acid content is initially 70 percent. Only the solution at 0 amperehour is 70 percent, since $\mathrm{HClO}_{4}$ reacts to form $\mathrm{Pb}\left(\mathrm{ClO}_{4}\right)_{2}$ as the battery dis. charges. A 70-percent battery at 20 ampere-hours therefore refers to a battery in which the solution contains only 47.2 percent of $\mathrm{HClO}_{4}$ and 13.2 percent of $\mathrm{Pb}$.
}

TABLE 20. Theoretical capacity of battery before acid concentration falls to 10 percent

\begin{tabular}{|c|c|}
\hline $\begin{array}{c}\text { Initial perchlo- } \\
\text { ric-acid solution, } \\
1,000 \mathrm{~g}\end{array}$ & $\begin{array}{c}\text { Theoretical } \\
\text { capacity }\end{array}$ \\
\cline { 1 - 2 }$\% \mathrm{HClO}_{4}$ & $\begin{array}{c}\text { amp-hr } \\
70\end{array}$ \\
60 & 72.1 \\
50 & 60.1 \\
40 & 48.1 \\
30 & 36.1 \\
& 24.0 \\
\hline
\end{tabular}

(e) Summary

The resistivities of aqueous solutions of perchloric acid and lead perchlorate of the composition of solutions in the NBS battery during discharge have been measured for solutions from 30 to 70-percent initial $\mathrm{HClO}_{4}$ content. These measurements extended from $-40^{\circ}$ to $+75^{\circ} \mathrm{C}$. In each of these solutions the resistivity increases as the battery discharges, i. e., as $\mathrm{Pb}^{++}$ions replace $\mathrm{H}^{+}$ions in solution. At room temperature and above, the rate of change of the 40-, 50-, $60-$, and 70-percent-acid battery solutions during discharge is constant. At lower temperatures, especially at $-25^{\circ}$ and $-40^{\circ} \mathrm{C}$, the 70 -percentacid battery solution increases much more rapidly during discharge than do the 50- and 60-percentacid solutions.

The author acknowledges the contributions to this series of measurements made by Belen G. Pardo, now of Manila, P. I., whose care and patience in taking much of the data made possible the high precision obtained in the measurements. Acknowledgment is also made of the contribution of Elinor H. Ostrander in assisting in the observations of electrical resistivity of perchloric-acid solutions.

The author also expresses her grateful appreciation to G. W. Vinal, under whose supervision the work on the perchloric-acid battery and the measurements reported in this paper were carried out. Dr. Vinal's suggestion of the problem and his help in carrying out the various measurements are gratefully acknowledged. 


\section{References}

[1] A. E. Markham, J. Am. Chem. Soc. 63, 874 (1941).

[2] G. F. Smith and O. E. Goehler, Ind. Eng. Chem. Anal. Ed. 3, 61 (1931).

[3] K. van Emster, Z. anorg. Chem. 52, 278 (1907).

[4] H. J. van Wyk, Z. anorg. Chem. 48, 41 to 45 (1906).

[5] J. R. Coe, Jr. and T. B. Godfrey, J. Applied Phys. 15, 625 (1944).
[6] H. J. van Wyk, Z. anorg. Chem. 48, 44 to 50 (1906).

[7] G. W. Vinal and D. N. Craig, J. Research NBS 13, 695 (1934) RP738.

[8] H. J. van Wyk, Z. anorg. Chem. 48, 6 to 29 (1906).

[9] J. P. Schrodt, W. J. Otting, Jr., J. O. Schoegler, and D. N. Craig, Trans. Electrochem. Soc. 90, 449 (1946).

Washington, June 3, 1948. 